\title{
Petrology and Geochemical Characteristic of Granitoids From Guéra Massif in the Central Part of Chad: An Example of Mixing Magmas
}

\author{
Diontar Mbaihoudou ${ }^{1,2}$, Kwékam Maurice ${ }^{2}$, Fozing Eric Martial ${ }^{2}$, Kagou Dongmo Armand ${ }^{2}$, Tcheumenak Kouémo Jules ${ }^{3}$ \\ ${ }^{1}$ Laboratoire de Géologie, Département de Génie Géologique, Université Polytechnique de Mongo, Tchad \\ ${ }^{2}$ Laboratoire de Géologie de 1’Environnement (LAGE), Faculté des Sciences, Université de Dschang, B.P. 67 Dschang, \\ Cameroun \\ ${ }^{3}$ Département Sciences de la Terre, Université de Douala, Cameroun \\ Correspondence: Kwékam Maurice, Laboratoire de Géologie de l’Environnement (LAGE), Faculté des Sciences, \\ Université de Dschang, B.P. 67 Dschang, Cameroun
}

\author{
Received: April 7, 2020 \\ Accepted: June 8, $2020 \quad$ Online Published: July 6, 2020 \\ doi:10.5539/esr.v9n2p66 \\ URL: https://doi.org/10.5539/esr.v9n2p66
}

\begin{abstract}
The granitoids of Guéra Massif are composed of biotite-granite, amphibole-biotite granite and gabbro-diorite and commonly contain micro granular mafic enclaves which vary from monzogabbro to syenite composition. They are metaluminous, high-K calc-alkaline to shoshonitic series. Gabbro-diorite rocks are magnesian while amphibole-biotite granites are magnesian to ferroan, and biotite granites are ferroan. They are enriched in LREEs relative to HREE and display negative anomalies in $\mathrm{Nb}, \mathrm{Ta}$ and Ti. Fields relationships, petrology and geochemistry indicate that mixing and mingling processes could be more relevant for the genesis of granitoids associated to fractional crystallization. Thus, the presence of mafic enclaves of gabbro-diorite composition in the granites, the resumption of alkaline feldspar xenocrystals in the gabbro-diorites, as well as the linear correlation between the granites and the gabbro-diorites and the intermediate position of the mafic enclaves between the two formations, enable us to propose magmatic mixing as the major process that presided over the evolution of the Guéra granitoids. The delamination of the continental lithosphere during the post-collisional phase of the Pan-African orogeny would have caused the partial melting of the subduction-modofied mantle and lower continental crust and thus produced the magmas of the Guéra granitoids.
\end{abstract}

Keywords: Guéra massif, gabbro-diorite, enclaves, high-k magnesian-ferroan granitoids, mixing

\section{Introduction}

Granitoids form the major part of continents (Clarke, 1992). They show in addition, a very great diversity in their petrogenesis and geochemistry. This diversity was used to determine their source, origin and evolution in relation to their geodynamic environment of genesis and emplacement (Hutton, 1988; Barbarin, 1999). Another characteristic of these granites is their richness in hosted mafic enclave that may retain important information on crust-mantle interaction and thus are significant for study of crustal growth and differentiation. Furthermore, magma mixing and mingling between mantle-derived mafic magmas and crust-derived felsic magmas is one of the key processes underlying magma differentiation and have been used widely to explain the origin of granitoids (Collins, 1996; Elburg and Nicholls, 1995; Keay et al., 1997; Kemp et al., 2007). The Precambrian basement exposed in the Guéra massif in central Chad is part of the Pan-African Central Africa Orogenic Belt (Fig. 1) separating the Congo craton to the south, the West African craton to the west and the Sahara metacraton to the north (Bessoles et Trompette, 1980; Black et Liégeois, 1993; Abdelsalam et al., 2002, Liégeois et al., 2013). It is made of Neoproterozoic juvenile crust composed of granitoids and enclaves (Kasser, 1995; Doumnang, 2006; Penaye et al., 2006; Isseini, 2011). Field relationships and geochemical trends have led many authors to argue that mixing between two end-member magmas underlies the evolution of granitoid (Collins, 1998; Gray, 1984; Gray and Kemp, 2009; Keay et al., 1997). Moreover, the heat sources for the production of its magma still remaining controversial (Nabelek and Liu, 2004).

Contrary to previous works that proposed magmatic mixing to explain isotope heterogeneities, this paper is essentially based on good field observations. Thus, this paper investigates magma mixing and mingling by linking better field observation and petrographic evidence with whole rock major and trace-element from granitoids of Guéra massif in which mafic enclaves are commonly observed in order to better constraints their source nature and their mechanism for the formation, which in turn might have great significance in understanding of the Proterozoic crustal evolution in the 
southern of Sahara Metacraton. Indeed, in the locality of Bitkine outcrop large slabs and domes of granitoids that offer very good structures of magmatic breccias and swarms of microgranular basic enclaves in the granites reminiscent of incomplete mixing of magmas.

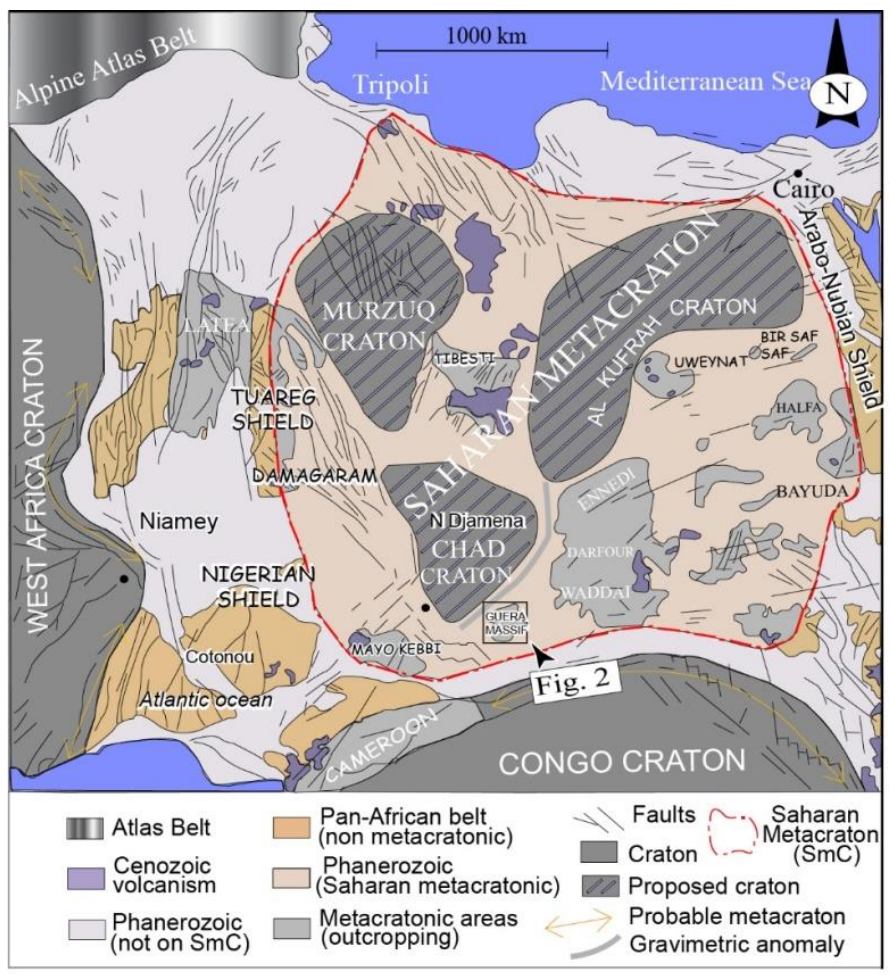

Figure 1. Geological sketch map of west-central Africa with cratonic areas and the Pan-African-Brasiliano provinces of the Pan-Gondwana belt in a Pangea reconstruction; modified from Castaing et al. (1994) and Abdelsalam et al. (2002), after (Liégeois et al., 2013)

\section{Geological Background}

The Precambrian basement in Chad is comprised of four major massifs. The Tibesti massif (located in the north), the Ouaddaï massif (located in the east), the Guéra massif in the centre and the Mayo Kebbi massifs in the south and southwest (Fig. 1). The Guéra Massif, one of the smallest massifs within the Saharan Metacraton, is composed about of $90 \%$ of magmatic and metamorphic rocks (Fig. 2) and inferred Neoproterozoic age buried under a sedimentary cover dominated by Quaternary alluvium. In addition, the Guéra Massif is comprised of volcanic and intrusive facies and meta-sedimentary (schist, marbles, quartzite, paragneiss and orthogneiss) and meta-volcanic (amphibolite, meta-andesite) sequences that are partially buried under Quaternary alluvium (Fig. 2; Isseini et al., 2013). They are composed of two types of granite (older granite and younger ones). The older granites (595 $\pm 8 \mathrm{Ma}, 589 \pm 6 \mathrm{Ma}$, method U-Pb on insitu zircons) are metaluminous to peraluminous, magnesian and alkali-calcic to calc-alkalic in composition (Pham et al., 2017). They are volcanic-arc-type, indicating the subduction zone and the subsequent collision between the southern Saharan Metacraton and the Congo Craton continued in the east after collision occurred in the west (Cameroon). The younger ones can be separated into two groups based on their emplacement age (570 Ma or $\leq 560 \mathrm{Ma}$ ). They are peraluminous, ferroan and calc-alkalic. Whole rock compositions and petrological modeling indicate that these granites were derived by melting of crustal materials but the whole rock are characteristic of a mantle source. The granitic rocks of the Guéra Massif range in age from $595 \pm 8 \mathrm{Ma}$ to $556 \pm 7 \mathrm{Ma}$ (method $\mathrm{U}-\mathrm{Pb}$ on insitu zircons) indicating they are related to tectonomagmatic processes associated with the collisional (> $590 \mathrm{Ma}$ ) and post collisional (<590 Ma) stages of the Central African Fold Belt (Pin and Poidevin, 1987; Kusnir and Moutaye, 1997; Abdelsalam et al., 2002; Toteu et al., 2004; Pouclet et al., 2006; Ngako et al., 2008; Shellnutt et al., 2017). Based on geophysical studies, Louis (1970) suggests the existence of a suture zone in the region, as evidenced by Bouger anomalies positive Ounianga-Massenya. The contrasting inheritance-rich nature of the granites with a juvenile $\mathrm{Nd}$ isotopic signature is likely due to mixing between magmas derived from juvenile (Neoproterozoic) arc-related crust and asthenospheric magmas (Shellnutt al., 2017). 


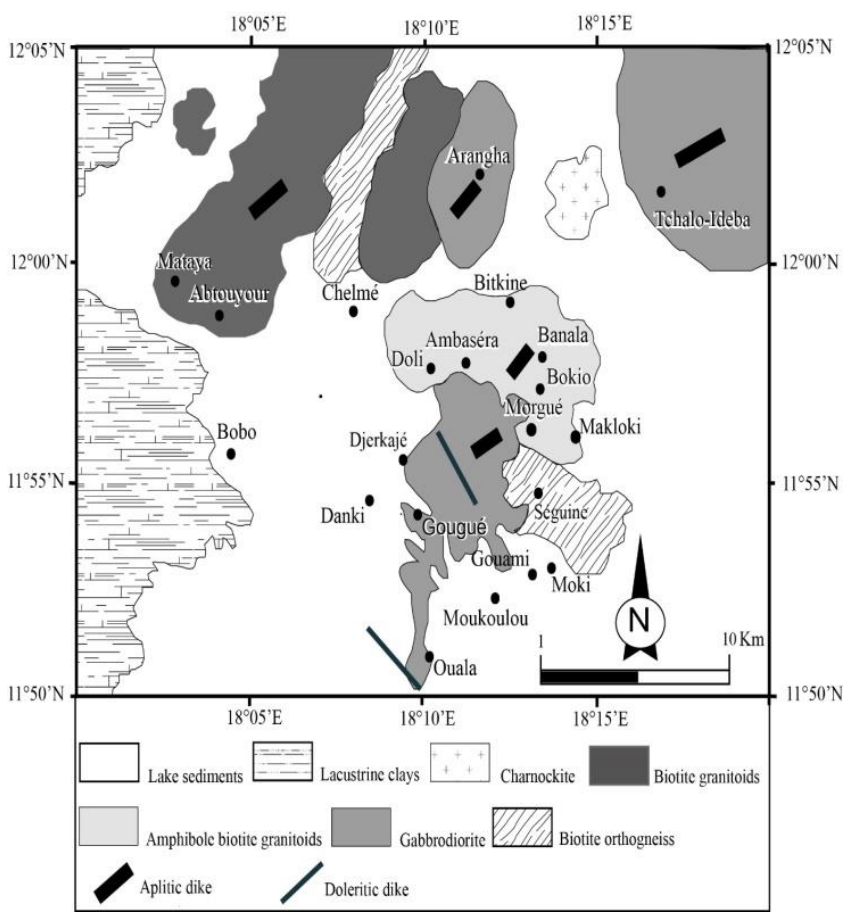

Figure 2. Geological map of the Guéra Massif

\section{Fields Relationship and Petrography}

In the Guéra massif, the main rocks type (crop out as flagstone or bowls) consists of biotite-granite (BG), amphibole-biotite granite (ABG) and gabbro-diorite (GD) (Fig. 2). The contacts between GD and ABG are brecciated (Fig. 3a). ABG are crosscut by sinistral N-S trending mafic dykes (GD) and E-W aplitic dykes (consisted of BG), which can exhibit cooling rims (Fig. 3d). Textures of granitoid vary from preserved igneous fabric with K-feldspar defining strongly magmatic fabric in the porphyritic sample to strongly foliated (Fig. 3e). Rapakivi feldspars occurring in the ABG (Fig. 3f). Microgranular mafic enclaves (MMEs) are common in ABG and in GD, but scarce in the BG. The MMEs are mostly more mafic than their host-rocks. They are rounded lens shaped or angular and brecciated and centimeter to decimeter in size. Some of them are elongated-ellipsoidal shaped. Size of long axis of enclaves is ranging from centimeter to meter and defined N-S magma foliation (Fig. 3b). The boundaries between mafic enclaves and host rock commonly have sharp; seldom gradually. The sharp contacts with granitoid are sometimes locate and commonly underlined by finer-grain-rize. A mafic intruded and mingled with the host granite which were partially crystallized because phenocryst of host granite was transferred to microgranular enclaves as xenocryst (Fig.3b). Plutonic dykes often disrupted into enclave swarms exchange of crystals (xenocrysts) of K- feldspar were observed (Fig. 3f).

\subsection{Amphibole-Biotite Granite ( $A B G)$}

ABG outcrop as bowls and flagstone at Doli, Ambasera, Banala, Bokio and Morgue localities (Fig. 2 and 3d). In the field, they are grey to dark-grey in colour and made up of K-feldspar megacryst (up to $2 \mathrm{~cm}$ ), quartz, plagioclase, amphibole and biotite as major minerals with porphyritic texture while zircon, apatite and oxides occurred as accessory minerals. The preferred orientation of those K-feldspar megacryst define a magmatic foliation. Some crystals display micro-fractures filled with quartz. Under the petrographic microscope, K-feldspar (40\%) is euhedral to subhedral and contains inclusions of grains of quartz. Quartz (25\%) is anhedral and present as large crystals with homogeneous extinction. Plagioclase (18\%) forms automorphic tabular crystals. Some crystals are zoned and altered to sericite (Fig. 4a). Plagioclase phenocrysts were rim resorbed. Sometimes it develops pertithic texture. Amphibole (15\%) is euhedral and subhedral and is partially chloritized. Biotite (6\%) forms small dark brown crystals dispersed in the rock. Its abundance is variable, giving to this granite a mesocratic to leucocratic aspect. Biotite occurs as flakes of various dimensions that may be clustered.

\subsection{Biotite Granites $(B G)$}

BG are common in the Arangha and Mataya localities in the north part of the pluton (Fig. 2). They are small grain size (40 x $60 \mathrm{~cm}$ ) and outcrop as vein oriented E-W, showing clear contact with the biotite orthogneiss and gabbro-diorite (Fig. 2 and 3d). Rocks are grey to grey-dark in color medium-to fine-grained, displaying granular textures. They are also 
composed of quartz (25-30\%), K-feldspars (45-50\%), plagioclase (15-20\%) and biotite (3\%). as ABG, but differ by the absence of amphibole (Fig. 4b). The accessory minerals are represented by zircon, apatite and oxides. Microscopic observation shows that, quartz occurs as anhedral to subhedral with homogeneous extinction and a late interstitial phase crystals with homogeneous extinction. Biotite is pleochroic from brown to yellow and partially chloritized. Some plagioclase grains contain small anhedral K-feldspath crystals. K-Alkali feldspars are large, anhedral to subhedral.

\subsection{Gabbro-Diorite (GD)}

Gabbro-diorite outcrop as elongated bands along the north and south part of the pluton (Fig. 2 and 3c-d). Apart from the presence of clinopyroxene, these rocks contains a similar mineralogical assemblage with ABG. The rocks are dark-grey in color and display fine to coarse grain texture. Plagioclase (30-40\%) occurs mainly as medium to coarse, tabular, subautomorphic grains forming aggregates with other groundmass minerals, mainly quartz, biotite and sometimes amphibole. Some of the plagioclase grains contain inclusions of quartz and biotite while small plagioclase is observed in inclusions in larger crystals. Amphibole (20-25\%) is yellowish green to brownish green or dark green and occurs as xenomorphic to subautomorphic, medium-to coarse grains, commonly associated with clinopyroxene and biotite (Fig. 4c). Amphibole is sometimes appears to be replaced by biotite xenomorphs (Fig. 4c). Pyroxene (10-15\%) is the clinopyroxene and occurs as sometimes relics in the amphibole (Fig. 4d). Biotite (5-15\%) (yellow-brown) occurs as medium-grained size, blade or flakes. It is intimately associated with hornblendes and pyroxene to which it replaces. K-feldspar (>15\%) appears as phenocryst euhedral rimmed by plagioclase crystals and sometimes were rim resorbed. The quartz $(>10 \%)$ occurs as rounded or ovoid to subhedral crystals (Fig. 4d). The accessory minerals are zircon, apatite and oxides.

\subsection{Enclaves (MMEs)}

The enclaves have black to dark gray color and are melanocratic and fine grained. They have generally microgranular but sometimes porphyritic textures due to the presence of plagioclase phenocrystal (Fig. 4e). Enclaves range in composition from monzogabbro in host gabbro-diorite, syenite in amphibole-granite and gabbro-diorite in biotite-granite. Most of the enclaves are microgranular and mafic than the host rock and are composed of plagioclase (40-45\%), amphibole (25-30\%), biotite (10-15\%), K-feldspar (>10\%), clinopyroxene (10-15\%) and quartz (>5\%). Zircon, acicular apatite (Fig. 4f) and oxides are accessory minerals. Chlorite is only secondary mineral which resulted from the hornblende alteration. $\mathrm{K}$-feldspar is as anhedral to subhedral crystals and sometimes contains mafic mineral inclusions. Alkali feldspar phenocrysts were rim resorbed (Fig. 4e). Plagioclase occurs mainly as medium to coarse, tabular, subautomorphic grains forming aggregates with other groundmass minerals, mainly quartz and biotite, occasionally hornblende. Some of the plagioclase grains contain inclusions of subrounded quartz and biotite. Amphibole is yellowish green to brownish green or dark green in color and occurs as subautomorphic to xenomorphic medium to coarse grains and commonly associated with pyroxene and biotite. Clinoyroxene occurs as phenocryst euhedral to subhedral. It is generally rimmed by amphibole. Some aggregates of hornblende and biotite interpreted to represent pseudomorphose after clinopyroxene are observed (Fig. 4g). Quartz is rounded and every so often occurs as ovoid grains (Fig. 4h). Biotite is yellow-brown and occurs as medium grained size. It appears as late mineral sometimes result of alteration of amphibole or pyroxene (Fig. 4h). The mineral assemblages of enclaves show that their chemical composition is similar to gabbro-diorite. They specific rocks are gabbroic-diorite and amphibole-biotite and biotite-granite. All the microgranular studied are enriched biotite and contain abundant green hornblende and small amount quartz. Monzogabbroic- and dioritic enclaves have I-type mineral assemblages that are broadly similar to those in the host granitoids except for the greater abundance of mafic minerals, such as biotite. They are mostly more mafic than their host rocks.

\section{Analytical Methods}

Twenty-five samples were collected from different petrographic types including (5 samples) for gabbro-diorite, (5 samples) for biotite granite, (5 samples) for amphibole biotite granite and (10 samples) for enclaves. Seventeen representative samples were analyse in the commercial ACME Analytical Laboratories Ltd, Vancouver, Canada, for whole-rock chemical analysises and results are in Table 1. Representative Major and trace elements data of granitoids from the Guéra Massif are listed in Table 1. Whole rock analyses for major and trace elements were carried out by Inductively-Coupled Plasma Mass Spectrometry (ICP-MS) from pulps. $0.2 \mathrm{~g}$ of rock powder was fused with $1.5 \mathrm{~g}^{2} \mathrm{BO}_{2}$ and then dissolved in $100 \mathrm{~mm}^{3} 5 \% \mathrm{HNO}_{3}$. The REE contents were determined by ICP-MS from pulps after $0.25 \mathrm{~g}$ rock-powder was dissolved with 4 acid digestions. Analytical precisions vary from $0.1 \%$ to $0.04 \%$ for major elements; from 0.1 to $0.5 \mathrm{ppm}$ for trace elements and from 0.01 to $0.5 \mathrm{ppm}$ for rare earth elements. More information on the procedure, precision and accuracy of ACTLABS FUS- ICP and FUS-MS analyses could be found at www.actlabs.com. 
Table 1. Results of major and trace elements analyse

\begin{tabular}{|c|c|c|c|c|c|c|c|c|c|c|c|c|c|c|c|}
\hline \multirow{2}{*}{ Symbol } & \multicolumn{3}{|c|}{ Biotite Granite } & \multicolumn{3}{|c|}{ Amphibolie-Biotite Granite } & \multicolumn{5}{|c|}{ Gabbro-diorite } & \multicolumn{4}{|c|}{ Enclaves } \\
\hline & BIT & & & BIT & BIT & BIT & & & & & & & & & \\
\hline$(\mathrm{W} t \%)$ & 35 & BIT 36 & BIT $31 \mathrm{~A}$ & 23 & $13 \mathrm{~A}$ & $29 \mathrm{~A}$ & BIT 22 & BIT $29 B$ & BIT 31B & BIT 27 & BIT 49 & BIT 48 & BIT $12 \mathrm{C}$ & BIT 41 & BIT 28 \\
\hline $\mathrm{SiO}_{2}$ & 71.9 & 70.79 & 73.95 & 68.76 & 65.19 & 53.38 & 52.89 & 51.27 & 56.49 & 55.09 & 61.03 & 59.08 & 50.35 & 60.43 & 48.60 \\
\hline $\mathrm{Al}_{2} \mathrm{O}_{3}$ & 14.2 & 14.78 & 14.23 & 15.48 & 14.64 & 15.65 & 14.08 & 12.98 & 13.57 & 13.40 & 16.43 & 12.22 & 12.25 & 17.66 & 14.05 \\
\hline $\mathrm{Fe}_{2} \mathrm{O}_{3}(\mathrm{t})$ & 2.62 & 3.00 & 1.71 & 3.68 & 4.57 & 10.49 & 11.34 & 10.91 & 10.80 & 8.29 & 6.39 & 6.72 & 9.48 & 6.24 & 9.80 \\
\hline $\mathrm{TiO}_{2}$ & 0.33 & 0.33 & 0.13 & 0.44 & 0.59 & 2.33 & 2.72 & 2.68 & 2.45 & 1.28 & 0.87 & 0.70 & 1.15 & 0.88 & 1.45 \\
\hline $\mathrm{MnO}$ & 0.04 & 0.04 & 0.03 & 0.06 & 0.11 & 0.14 & 0.13 & 0.15 & 0.13 & 0.12 & 0.09 & 0.16 & 0.16 & 0.08 & 0.15 \\
\hline $\mathrm{MgO}$ & 0.53 & 0.49 & 0.20 & 1.08 & 2.28 & 4.19 & 4.00 & 6.21 & 2.66 & 7.18 & 3.48 & 6.32 & 11.52 & 0.98 & 9.76 \\
\hline $\mathrm{CaO}$ & 1.23 & 1.63 & 1.11 & 2.79 & 3.30 & 7.32 & 6.49 & 7.08 & 6.08 & 7.39 & 4.72 & 6.22 & 7.22 & 3.10 & 7.58 \\
\hline $\mathrm{Na}_{2} \mathrm{O}$ & 4.09 & 4.12 & 4.09 & 3.88 & 3.65 & 3.48 & 3.30 & 2.69 & 3.03 & 2.94 & 3.85 & 1.62 & 1.88 & 4.74 & 2.78 \\
\hline $\mathrm{K}_{2} \mathrm{O}$ & 4.78 & 4.62 & 4.64 & 3.28 & 3.48 & 2.58 & 2.44 & 3.13 & 2.97 & 2.64 & 2.85 & 5.61 & 4.06 & 5.72 & 2.63 \\
\hline $\mathrm{P}_{2} \mathrm{O}_{5}$ & 0.11 & 0.10 & 0.03 & 0.14 & 0.18 & 0.60 & 1.44 & 0.88 & 0.96 & 0.77 & 0.28 & 0.20 & 0.62 & 0.22 & 0.46 \\
\hline LOI & 0.41 & 0.37 & 0.36 & 0.58 & 0.69 & 0.37 & 0.72 & 0.38 & 0.41 & 1.19 & 0.42 & 0.89 & 1.31 & 0.34 & 1.21 \\
\hline $\begin{array}{l}\text { Total } \\
\text { (ppm) }\end{array}$ & 100 & 100.3 & 100.5 & 100.2 & 98.7 & 100.5 & 99.5 & 98.4 & 99.5 & 100.3 & 100.4 & 99.7 & 100.0 & 100.4 & 98.5 \\
\hline $\mathrm{Sc}$ & 3 & 3 & 3 & 5 & 13 & 19 & 13 & 20 & 14 & 17 & 12 & 13 & 27 & 8 & 20 \\
\hline $\mathrm{V}$ & 18 & 19 & 8 & 44 & 52 & 216 & 173 & 217 & 166 & 146 & 103 & 94 & 185 & 40 & 175 \\
\hline $\mathrm{Ba}$ & 884 & 897 & 359 & 1381 & 569 & 1314 & 2139 & 1461 & 1411 & 1320 & 1276 & 6333 & 1433 & 2343 & 873 \\
\hline $\mathrm{Sr}$ & 401 & 426 & 144 & 657 & 499 & 819 & 1146 & 892 & 572 & 1022 & 803 & 658 & 704 & 474 & 706 \\
\hline $\mathrm{Y}$ & 10 & 10 & 20 & 14 & 22 & 25 & 20 & 24 & 31 & 30 & 17 & 19 & 25 & 22 & 18 \\
\hline $\mathrm{Zr}_{\mathrm{r}}$ & 160 & 163 & 92 & 112 & 185 & 222 & 359 & 365 & 400 & 241 & 246 & 155 & 255 & 925 & 367 \\
\hline $\mathrm{Cr}_{\mathrm{r}}$ & 20 & 30 & & 30 & 100 & 30 & 70 & 280 & & 330 & 140 & 430 & 1040 & & 640 \\
\hline Co & 3 & 4 & 1 & 6 & 11 & 32 & 30 & 37 & 25 & 33 & 16 & 24 & 46 & 8 & 46 \\
\hline $\mathrm{Ni}$ & & & & & 30 & & & 60 & & 190 & 40 & 170 & 140 & & 300 \\
\hline $\mathrm{Cu}$ & & & & 10 & 10 & 10 & 20 & 30 & 20 & 20 & 20 & & 30 & & \\
\hline $\mathrm{Zn}$ & 50 & 60 & 50 & 70 & 100 & 100 & 160 & 110 & 140 & 120 & 80 & 100 & 130 & 100 & 120 \\
\hline $\mathrm{Ga}$ & 23 & 23 & 20 & 20 & 21 & 24 & 25 & 23 & 26 & 20 & 22 & 16 & 16 & 26 & 22 \\
\hline $\mathrm{Ge}$ & 1 & 1 & 1 & 1 & 1 & 1 & 1 & 1 & 2 & 2 & 1 & 1 & 2 & 1 & 1 \\
\hline $\mathrm{Rb}$ & 164 & 148 & 219 & 91 & 119 & 75 & 66 & 88 & 145 & 69 & 83 & 72 & 125 & 79 & 96 \\
\hline $\mathrm{Nb}$ & 8 & 8 & 6 & 4 & 8 & 17 & 24 & 17 & 24 & 8 & 6 & 5 & 12 & 12 & 12 \\
\hline $\mathrm{Sn}$ & 4 & 3 & 5 & 1 & 3 & 2 & 2 & 3 & 8 & 2 & 2 & 2 & 2 & 1 & 3 \\
\hline $\mathrm{Cs}_{\mathrm{s}}$ & 3.9 & 4.7 & 3.1 & 2.2 & 1.9 & 0.6 & 0.7 & 0.7 & 3.2 & 6.1 & 1.5 & & 1.9 & & 1.7 \\
\hline $\mathrm{La}$ & 31.7 & 37.1 & 26.1 & 25.4 & 35.5 & 45.8 & 91.6 & 67.2 & 76.7 & 77.1 & 43.7 & 18.3 & 36.7 & 40.4 & 35.9 \\
\hline $\mathrm{Ce}$ & 69.2 & 73.3 & 56.6 & 50.5 & 72.8 & 101 & 191 & 149 & 160 & 168 & 84.7 & 51.6 & 80.7 & 81.7 & 86.1 \\
\hline $\mathrm{Pr}$ & 6.97 & 7.99 & 6.77 & 5.94 & 9.77 & 12.6 & 22.8 & 17.8 & 18.7 & 20.8 & 9.57 & 7.88 & 10.1 & 9.96 & 11.2 \\
\hline $\mathrm{Nd}$ & 24.8 & 29.5 & 25.7 & 22.8 & 38 & 51.2 & 89.9 & 70.8 & 72.1 & 87.3 & 36.8 & 33.9 & 41.6 & 39.7 & 46.5 \\
\hline $\mathrm{Sm}$ & 4.6 & 5.3 & 6.3 & 4.2 & 7.4 & 9.6 & 15.1 & 12.7 & 13.3 & 17.9 & 6.6 & 6.7 & 8.3 & 7.5 & 8.9 \\
\hline $\mathrm{Eu}$ & 1 & 1.03 & 0.44 & 1.28 & 1.3 & 2.63 & 4.31 & 2.88 & 3.35 & 4.49 & 1.62 & 1.83 & 2.02 & 2.21 & 2.17 \\
\hline $\mathrm{Gd}$ & 3.1 & 3.4 & 4.8 & 3.2 & 5.6 & 7.4 & 10 & 9.3 & 9.9 & 13.1 & 4.7 & 4.8 & 6.6 & 6.1 & 6.6 \\
\hline $\mathrm{Tb}$ & 0.4 & 0.4 & 0.7 & 0.4 & 0.8 & 1 & 1.1 & 1.2 & 1.3 & 1.5 & 0.6 & 0.6 & 0.9 & 0.9 & 0.8 \\
\hline Dy & 2.2 & 2.2 & 3.6 & 2.4 & 4.2 & 5.3 & 5.2 & 6 & 6.8 & 7 & 3.3 & 3.5 & 4.8 & 4.5 & 4.2 \\
\hline Ho & 0.4 & 0.4 & 0.6 & 0.4 & 0.8 & 0.9 & 0.8 & 1 & 1.2 & 1.1 & 0.6 & 0.7 & 0.9 & 0.8 & 0.7 \\
\hline $\mathrm{Er}_{\mathrm{r}}$ & 1 & 1 & 1.8 & 1.3 & 2.1 & 2.4 & 2 & 2.7 & 3.1 & 2.8 & 1.6 & 2 & 2.3 & 2.5 & 2 \\
\hline $\mathrm{Tm}$ & 0.14 & 0.14 & 0.25 & 0.19 & 0.29 & 0.31 & 0.25 & 0.37 & 0.42 & 0.36 & 0.23 & 0.29 & 0.32 & 0.36 & 0.26 \\
\hline $\mathrm{Yb}$ & 0.9 & 0.9 & 1.6 & 1.3 & 1.9 & 1.9 & 1.5 & 2.2 & 2.6 & 2.2 & 1.4 & 2 & 2.1 & 2.4 & 1.6 \\
\hline $\mathrm{Lu}$ & 0.14 & 0.15 & 0.25 & 0.2 & 0.3 & 0.31 & 0.21 & 0.32 & 0.39 & 0.35 & 0.22 & 0.31 & 0.32 & 0.39 & 0.23 \\
\hline Hf & 4.3 & 4.9 & 3.4 & 3.1 & 4.8 & 5.5 & 1.7 & 6.1 & 3.7 & 5.9 & 6.1 & 3.6 & 6.2 & 20.5 & 8.8 \\
\hline $\mathrm{Ta}$ & 1.4 & 1.5 & 1 & 0.6 & 0.8 & 1.1 & 1.6 & 1.1 & 2 & 0.6 & 0.4 & 0.3 & 0.8 & 0.8 & 0.6 \\
\hline $\mathrm{Pb}$ & 25 & 27 & 26 & 19 & 18 & 8 & 15 & 7 & 13 & 12 & 15 & 19 & 14 & 17 & 9 \\
\hline $\mathrm{Th}$ & 14.1 & 16.1 & 27.2 & 5.6 & 7.3 & 4.1 & 5.9 & 4.8 & 14.2 & 11.4 & 6.8 & 1.1 & 5.2 & 1.9 & 1.8 \\
\hline $\mathrm{U}$ & 3 & 3.2 & 6.8 & 1.7 & 1.5 & 0.7 & 1.4 & 0.9 & 2.7 & 2.8 & 1.3 & 0.4 & 1.4 & 1.3 & 0.8 \\
\hline $\mathrm{K}_{2} \mathrm{O} / \mathrm{Na}_{2} \mathrm{O}$ & 1.17 & 1.12 & 1.13 & 0.85 & 0.95 & 0.74 & 0.74 & 1.16 & 0.98 & 0.90 & 0.74 & 3.46 & 2.16 & 1.21 & 0.95 \\
\hline ANOR & 16.19 & 21.55 & 16.28 & 40.18 & 39.24 & 56.07 & 53.21 & 43.25 & 45.50 & 49.95 & 53.18 & 22.28 & 35.13 & 22.86 & 53.79 \\
\hline$Q^{\prime}$ & 26.66 & 25.50 & 30.09 & 27.54 & 22.55 & 1.35 & 7.34 & 0.04 & 14.90 & 4.46 & 13.10 & 10.40 & 0.00 & 1.22 & 0.00 \\
\hline $\mathrm{A} / \mathrm{CNK}$ & 1.04 & 1.01 & 1.04 & 1.04 & 0.94 & 0.74 & 0.78 & 0.66 & 0.75 & 0.66 & 0.93 & 0.62 & 0.62 & 0.91 & 0.68 \\
\hline $\mathrm{Eu} / \mathrm{Eu}^{*}$ & 0.09 & 0.08 & 0.05 & 0.09 & 0.62 & 0.96 & 1.08 & 0.82 & 0.85 & 0.90 & 0.89 & 0.99 & 0.84 & 1.01 & 0.87 \\
\hline$(\mathrm{La} / \mathrm{Yb})_{\mathrm{N}}$ & 21.35 & 24.98 & 9.89 & 11.84 & 11.32 & 14.61 & 37.01 & 18.51 & 24.20 & 21.24 & 18.92 & 5.55 & 10.59 & 10.20 & 13.60 \\
\hline
\end{tabular}




\section{Whole Rock Geochemistry}

\subsection{Major Elements}

In the Q'-ANOR diagram (Fig. 5a) after Streikeisen and Le Maitre (1979), the gabbro-diorite samples plot predominantly into the field of quartz monzodiorite to monzogabbro while amphibole biotite granite plots in to syenogranite-monzogranite fields. Biotite granite scatter within the fields of monzogranite and granodiorite (Fig. 5a). The enclaves are classified as tonalite, quartz syenite, syenite, monzodiorite and monzogabbro. The rocks show mostly subalkaline affinity, in the Total-Alkali-Silica (TAS) diagram (Fig. 5b; Middlemost 1985). They are high-K calc-alkalines to shoshonitic (Fig. 5c) and metaluminous to weakly peraluminous I-type granitoids $\left(\mathrm{A} / \mathrm{CNK}=0.59-1.03\right.$; Fig. 6a). According to the classification of granitoids by Frost et al. (2001) using $\mathrm{SiO}_{2}$ vs $\mathrm{Fe}^{*}$ number [molar $\left.\mathrm{FeOt} /(\mathrm{FeOt}+\mathrm{MgO})\right]$, gabbro-diorites and amphibole-biotite granite belong to mangnesian group and biotite granites are ferroan (Fig. 6c). Such in MALI diagram (Modified Alkali lime Index) of Frost et al. (2001) with increasing $\mathrm{SiO}_{2}$ composition of granitoids evolve mostly from calc-alkalic to alkali-calcic (Fig. 6b). $\mathrm{SiO}_{2}$ contents range from $49-61 \mathrm{wt} . \%$ in enclaves to $52.32-61.04 \mathrm{wt} . \%$ in the gabbro-diorites, are higher in the amphibole-biotite granite (60.04-70.84 wt.\%) and biotite granite (70.86-73.86 wt.\%). Harker diagrams show two groups with a general linear decrease in $\mathrm{TiO}_{2}, \mathrm{Fe}_{2} \mathrm{O}_{3}, \mathrm{CaO}, \mathrm{MnO}, \mathrm{MgO}$ (Fig. 7). $\mathrm{Al}_{2} \mathrm{O}_{3}$ and $\mathrm{P}_{2} \mathrm{O}_{5}$ increase in Gabbro-diorite and Enclaves, and decrease in both granites with increasing $\mathrm{SiO}_{2}$.
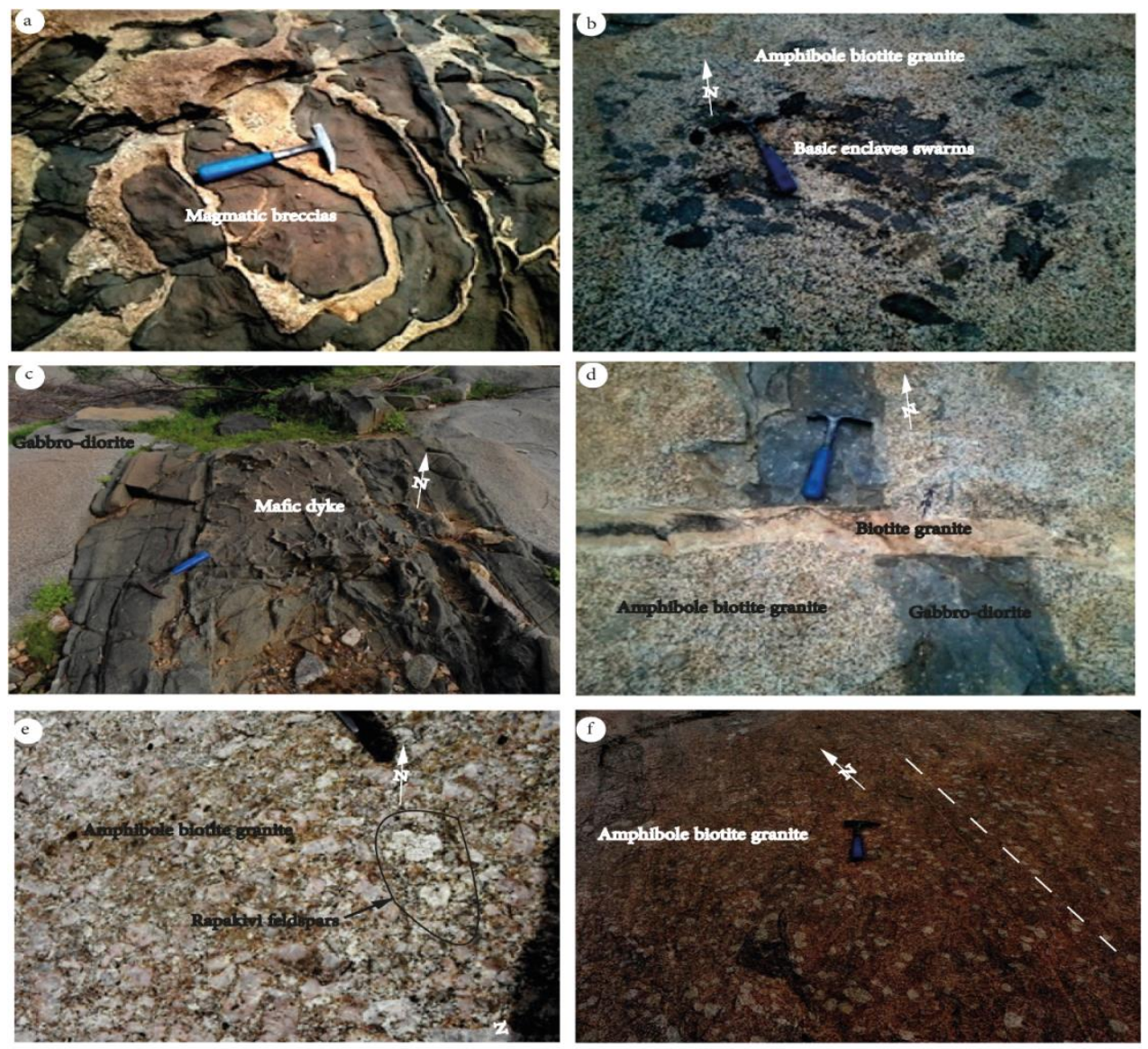

Figure 3. Field photographic showing, (a) Magmatic breccias. Noticeable acidic magma was then forcibly intruded into the solid mafic mass, (b) enclave swarms within amphibole-biotite granite, (c) late-stage mafic dyke in granite. Noticeable is the brittle fracturing displayed by the dyke, (d) gabbrodiorite and amphibole biotite crosscut ENE-WSW trending by

biotite granite, (e) Rapakivi feldspar occurring in the amphibole biotite granite, (f) Dispersed euhedral K-feldspar megacrysts aligned in a magmatic flow foliation oriented N-S. Noticeable: the agreement between enclave and feldspar foliation orientations is magmatic flow. (Hammer length $23 \mathrm{~cm}$, pencil length $10 \mathrm{~cm}$ ) 

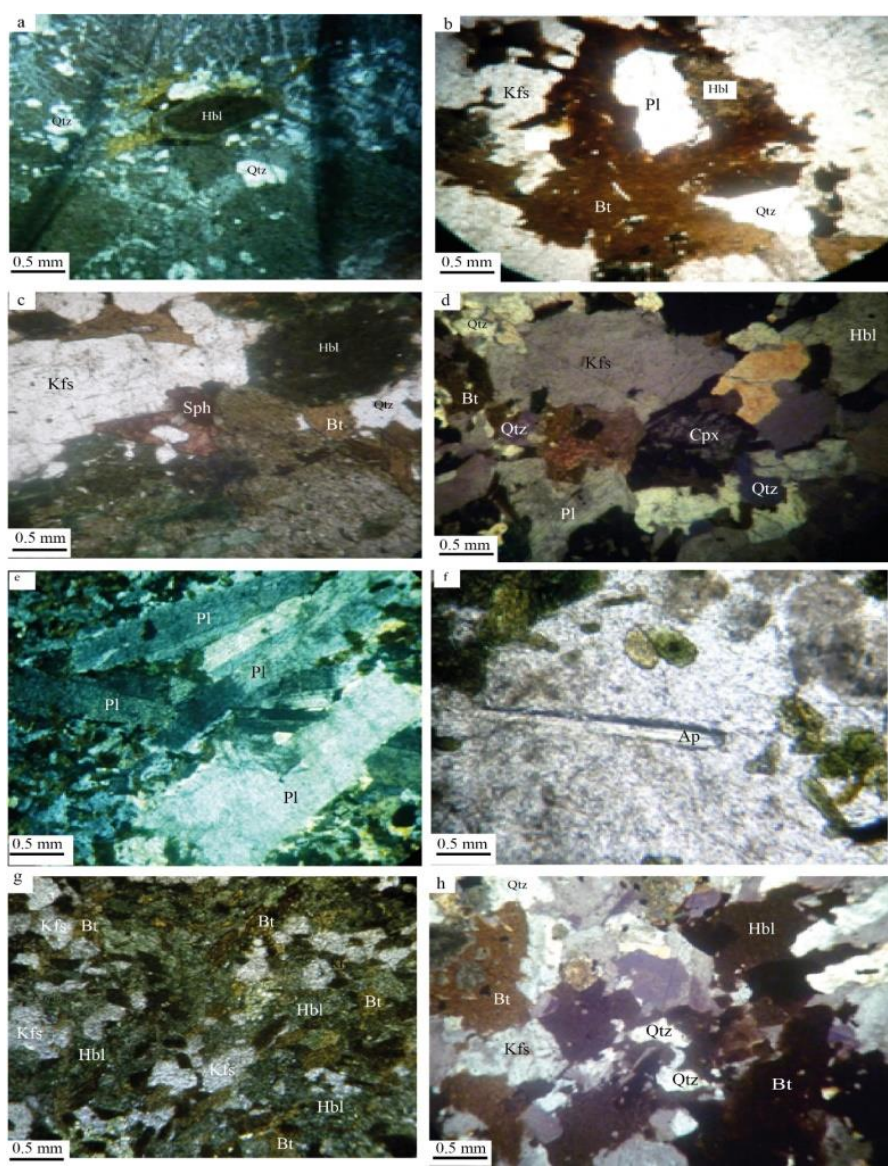

Figure 4. photomicrographs showing typical textures of mixing and mingling structure, (a) plagioclase zoning within amphibole biotite granite, (b) Plagioclase phenocrysts were rim resorbed, (c) biotization of amphibole in mafic enclave, (d) relics of clinopyroxene in the amphibole within gabbro-diorite, (e) The ovoid grains of quartz in the gabbro-diorite, (f) Alkali feldspar phenocrysts were rim resorbed in the mafic enclaves, $(\mathrm{g})$ dendritic plagioclase in within mafic enclave, (h) aggregates of hornblende $(\mathrm{Hbl})$ and biotite $(\mathrm{Bt})$ interpreted to represent pseudomorphs after clinopyroxene (cpx) within mafic enclaves 

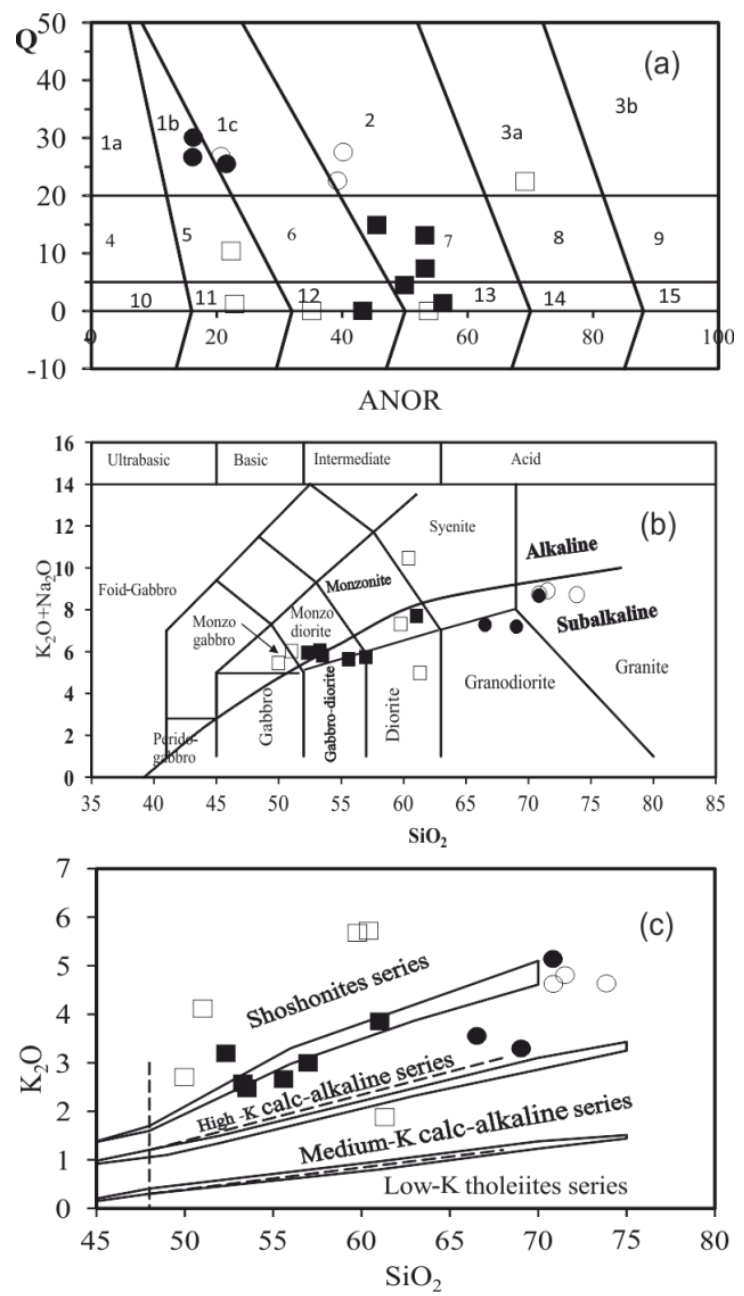

Figure 5. Plots of granitoids of Guéra massif in the rock classification diagrams (a) Q-ANOR diagram (after Streckeisen and Le Maitre, 1979), 1a : Alkali-feldspar granite,1b :Syenogranite, 1c :Monzogranite, 2 : Granodiorite, 3a : Tonalite, 3b : calcic tonalite, 4: alkali-feldspar Quartz Syenite, 5 : Quartz syenite, 6 : Quartz Monzonite, 7 :Quartz Monzodiorite, 8 : Quartz Diorite ,9: Quartz Gabbro, 10 : alkali-feldspar 11 :Syenite, 12 :Monzonite,13 : Monzogabbro, 14 :Diorite, 15 : Gabbro. (b) TAS diagram (Middlemost (1985): (c) $\mathrm{K}_{2} \mathrm{O}$ vs $\mathrm{SiO}_{2}$ diagram (after Rickwood, 1989). (Square: Enclaves, Solid square: gabbro-diorites, solid circle: amphibole-biotite granites and circle: biotite granites) 

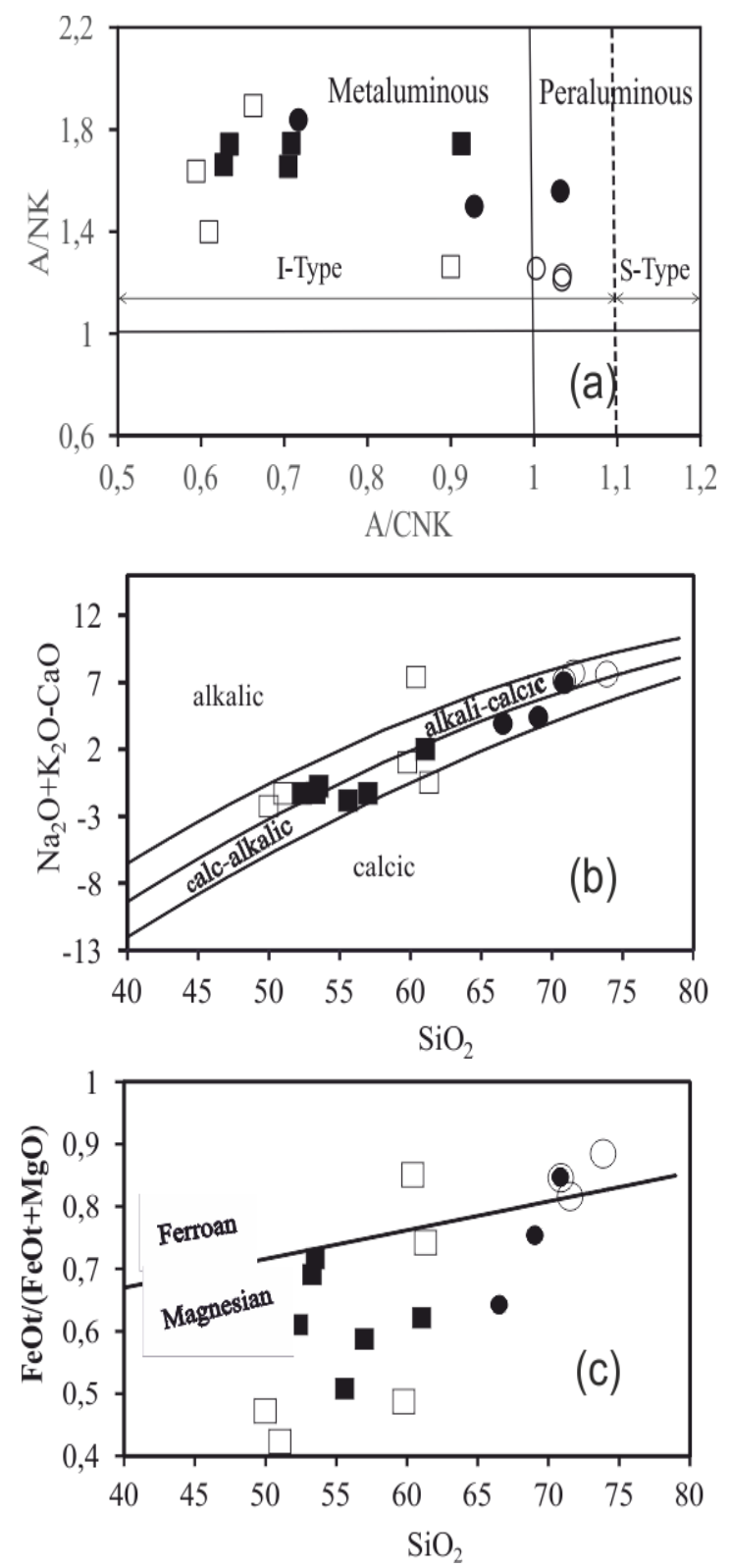

Figure 6. (a) A/NK vs A/CNK diagram after Maniar and Piccoli (1989), (b) $\mathrm{SiO}_{2}$ vs. $\left(\mathrm{Na}_{2} \mathrm{O}+\mathrm{K}_{2} \mathrm{O}-\mathrm{CaO}\right.$ ) diagram (Frost et al., 2001) and (c) $\mathrm{SiO}_{2}$ vs Fe*number diagram (Frost et al., 2001). (Square: Enclaves, Solid square: gabbro-diorites, solid circle: amphibole-biotite granites and circle: biotite granites) 

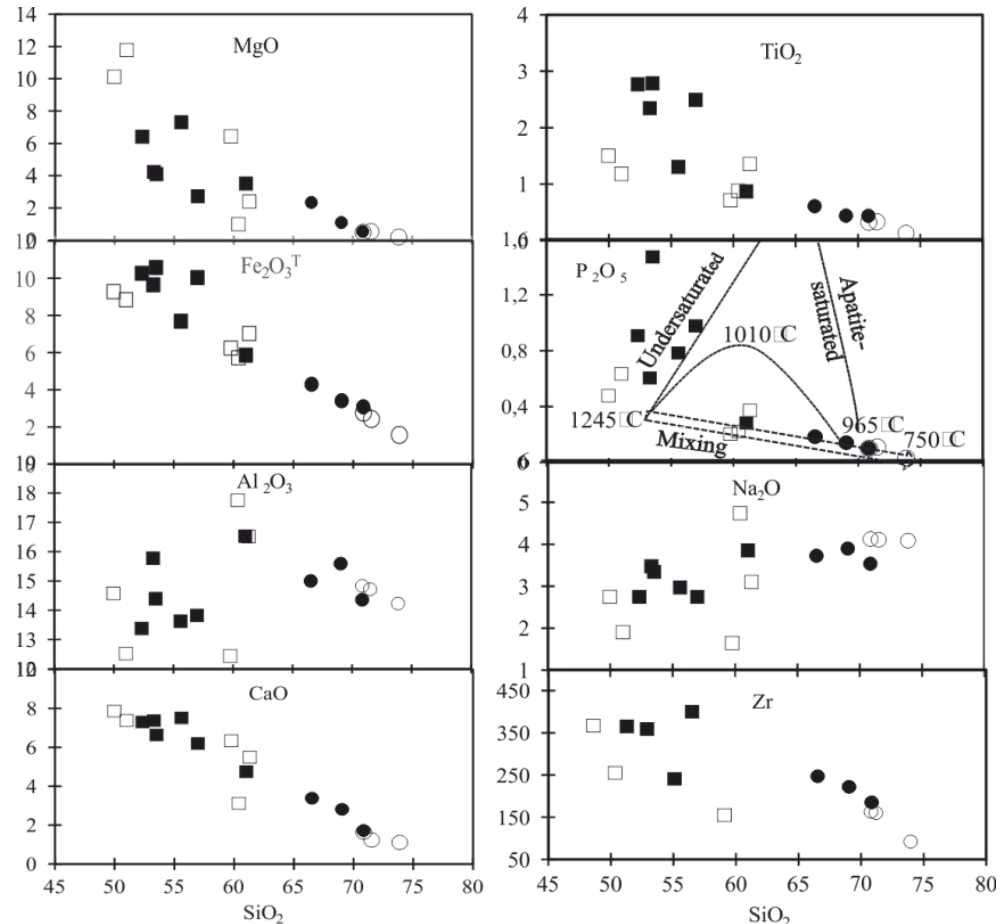

Figure 7. Harker variation diagrams for selected major elements expressed in oxides (weight \%) of granitoids from Guéra massif. Both granites and some enclaves samples are aligned to mixing trend I-type granitoids on $\mathrm{P}_{2} \mathrm{O}_{5} \mathrm{vs} \mathrm{SiO}_{2}$ plot (Chappell and White, 1992). (Square: Enclaves, Solid square: gabbro-diorites, solid circle: amphibole-biotite granites and circle: biotite granites)

\subsection{Trace and Rare Earth Elements}

They are highly variable from a group to another and even within each group. Primitive-normalized REE spider diagram (McDonough and Sun, 1995) show that (Fig. 8), the enclaves are enriched in LREE relative to HREE, have no negative Eu anomaly $\left(\mathrm{Eu} / \mathrm{Eu}^{*}=0.84-1.00\right)$, a steep HREE pattern, have a moderate fractionation with $(\mathrm{La} / \mathrm{Yb})_{\mathrm{N}}=5.55-13.6($ see table 1). The microgranular mafic enclaves are characterized by higher REE ( $\left.\sum R E E=134-207 \mathrm{ppm}\right)$ contents and a distribution profile comparable to that of the host rocks. Gabbro-diorites have high REE ( $\sum$ REE $\left.=126-436 \mathrm{ppm}\right)$ than microgranular enclaves. They are enriched in LREEs relative to HREE $\left((\mathrm{La} / \mathrm{Yb})_{\mathrm{N}}=14.61-37.01\right)$, have no negative Eu anomaly $\left(\mathrm{Eu} / \mathrm{Eu}^{*}=0.81-1.08\right)$. Amphibolite-biotite granites are moderated rich in REE ( $\left.\sum \mathrm{REE}=120-331 \mathrm{ppm}\right)$. They have a steep HREE pattern, are high fractionated $\left((\mathrm{La} / \mathrm{Yb})_{\mathrm{N}}=12.49-24.61\right)$ with strongly to moderated negative Eu anomalies $\left(\mathrm{Eu} / \mathrm{Eu}^{*}=0.40-0.96\right)$. Biotite-granites have less REE contents $\left(\sum \mathrm{REE}=135-163 \mathrm{ppm}\right)$. They are enriched in LREEs relative to HREE $\left((\mathrm{La} / \mathrm{Yb})_{\mathrm{N}}=9.89-24.98\right)$, have strongly and moderated negative Eu anomaly $\left(\mathrm{Eu} / \mathrm{Eu}^{*}=\right.$ 0.25-0.81), a steep HREE pattern, are high fractionated $\left.(\mathrm{La} / \mathrm{Yb})_{\mathrm{N}}=10.91-27.57\right)$. Both granites display sub-parallel REE patterns and strong negative Eu anomalies suggesting plagioclase crystallization. The primitive mantle-normalized multi-element diagram of McDonough and Sun (1995) shows a more pronounced enrichment in Large Ion Lithophile Elements (LILE) than high field strength elements (HFSE) relatively to the primitive mantle (Fig. 8). Enclaves display strongly positive anomaly in $\mathrm{Ba}$ and $\mathrm{Pb}$ while gabbro-diorite rocks show slightly positive anomaly in $\mathrm{Ba}$ and negative anomaly in $\mathrm{P}$ and $\mathrm{Zr}$ correlated to apatite and zircon crystallization. Both granites display negative anomalies in $\mathrm{Ba}$ associated to positive anomaly in $\mathrm{Pb}$. In addition, all analyzed samples show negative anomalies in $\mathrm{Nb}-\mathrm{Ta}$, $\mathrm{P}$, Ti that could been related to their tectonic environment.

\section{Discussion}

\subsection{Evidences of Mixing and Mingling}

Field observations such as those in Figure $3 \mathrm{a}$ and $\mathrm{b}$ are quite significant of the coexistence of two magmatic liquids, basic and acidic. Brecciated structures and swarms of microgranular mafic enclaves in the granite are clear evidence of magmatic mixing. These types of structures are well documented by several authors (Rollinson 1993; Castro et al., 1990; 1991a; Didier, 1987; Wiebe, 1996; Tobisch et al., 1997; Poli and Tommasini, 1999; Vernon, 1983; Wyllie, 1984; Barbarin and Didier, 1992). The presence of the syn-plutonic mafic dyke and enclaves in granitoids indicate contemporaneous presence of mafic and felsic magmas and magma mingling and mixing processes (Fig.3b, c and d). The presence of K-feldspar megacrysts in the mafic enclave may imply that they had a similar origin (Vernon, 1991), because K-feldspar 
megacryst-bearing microgranular enclaves are common in K-feldspar megacrystic granites. K-feldspar forms in the early stages of crystallization; moreover, the mechanical transfer of K-feldspar megacrysts from a more felsic magma into mafic magma has been suggested as a likely process (Fig.3f). The rimming of K-feldspars by plagioclase (Fig. 3f) is usually a result of magma mixing (Silva et al., 2000). Wiebe (1991 and 1994) and Hibbard (1991) have believed that chilled margin of mafic enclaves is a mingling evidence. Field relations show that the enclaves and foliation defined by aligned feldspars have similar orientations, suggesting either magmatic flow or crystal settling within the magma chamber (Fig.3b). The granitoid of Guéra massif have a mineralogical compositions dominated by abundant biotite, K-feldspar, subordinate amphibole and clinopyroxene. Therefore they may be compared to I-types series (Chappell and White, 1992) and more precisely to the KCG (K-rich and feldspar porphyritic calc-alkaline granitoids) or ACG (Amphibole-bearing calc-alkaline Granitoids) that result from mixing mantle and crustal magmas (Barbarin, 1999). One of the most important petrographic features observed in these samples is the presence of abundant resorbed crystals of plagioclase, alkali-feldspar and quartz (Fig.4). The zoning of plagioclase phenocryts in amphibole-biotite granite suggest involvement mixing process (Barbarin and Didier, 1992). The swarms of mafic enclaves in the granite and the clinopyroxene cores in the hornblende indicate that the hybridization process was not complete (Fig.3b). The presence of amphibole-rich enclaves within amphibole-biotite granite and gabbro-diorite indicate that fractional crystallization played a role during the early stages of the granitoid petrogenesis. Acicular apatite in mafic enclaves has also been identified as a mixing/mingling texture (Fig.4f).

Evidence for mixing between basic and acidic melts can be seen on both the outcrop and microscopic scales, and is also supported by linear and curvilinear differentiation trends on variation diagrams. A considerable good rectilinear trend has been obtained in the TAS plot for the granitoid of Guéra, strongly marking mixing of magma (Fig.5b). In Harker's diagrams the two lines of evolution converge towards the granites, thus attesting that the latter result from the mixing of two very different magma sources. This is best expressed in the $\mathrm{SiO}_{2} \mathrm{vs}_{2} \mathrm{O}_{5}$ diagram (Fig.7) where the two granites and some enclave samples are aligned on the mixing line and the gabbro-diorites follow the line of unsaturated apatite rocks. In addition, plots of $\mathrm{MgO}$ vs. $\mathrm{Fe}_{2} \mathrm{O}_{3}$ t diagram (Fig.9) after Zorpi et al. (1989) suggest that magma mixing was a major mechanism in the formation of the Guéra granitoids according to Langmuir et al. (1978). This magma mixing is further suggested by linear array of plots on the $\mathrm{Al}_{2} \mathrm{O}_{3} / \mathrm{TiO}_{2}$ vs. $\mathrm{CaO} / \mathrm{Na}_{2} \mathrm{O}$ (Fig.9a) and $\mathrm{Na}_{2} \mathrm{O} / \mathrm{CaO}$ vs. $\mathrm{Al}_{2} \mathrm{O}_{3} / \mathrm{CaO}($ Fig. 9 b), (Chappell \& White, 1992 and Sylvester, 1998) diagrams (Fig.9). The enrichment in large ion lithophile elements and depletion in high field strength elements (e.g., $\mathrm{Nb}, \mathrm{Ta}$, and Ti) of granitoid that imply a significant amount of crust material (Fig.8 and Fig.10c), was involved in their genesis most probably as a result of magma mixing (Langmuir et al., 1978; Pearce et al., 1984). The mafic enclaves are characterized by higher REE contents and a distribution profile comparable to that of the host rocks. Such geochemical similarity between mafic enclave and host rock is very common and testifies to mixing between the two magmas (Tindle, 1991). All of these data indicate significant magma mixing and mingling processes during the history of the Guéra granitoids.

\subsection{Evidences of Fractional Crystallization}

Whereas we have demonstrated above mixing and mingling magmas were important processes affecting the geochemical evolution of the granitoids, the inverse variation of $\mathrm{MgO}, \mathrm{Fe}_{2} \mathrm{O}_{3} \mathrm{t}$, and $\mathrm{CaO}$ with silica suggests that the primary minerals observed in thin section (plagioclase, biotite, and hornblende) accumulated or fractionated to produce the observed chemical variation (Fig.7, Fig. 9d and Fig. 10 a and b). General negative Nb, Ta, P, Ti anomalies in gabbro-diorites and granites attested the crystallization of accessory minerals like apatite, Ti-Fe oxide associated to the essential's minerals (biotite, hornblende; Fig.8). It is evident that fractional crystallization controlled much of the evolution of the magmas in the Guéra massif. The behaviour of $\mathrm{Al}_{2} \mathrm{O}_{3}$ compared to the behaviour of $\mathrm{CaO}, \mathrm{MgO}$ (Fig. 7), suggests that clinopyroxene controls the first phase of fractional crystallization followed by plagioclase (Fig. 10 a and b). Indeed, $\mathrm{Al}_{2} \mathrm{O}_{3}$ content increases in Gabbro-Diorites and microgranular mafic enclaves and decreases in both granites with increasing $\mathrm{SiO}_{2}$ content.

\subsection{Source Rock Characteristics}

The investigated granitoids of Guéra Massif exhibit petrographical and chemical compositions characteristic of high-K calc-alkaline to shoshonitic I-type granitoids (Chappell and White, 1992 and 1974) derived from partial melting of igneous protoliths. From the several studies carried out to constrain the generation of high-K magmas in convergent tectonic settings, two main processes are commonly recognized (Altherr et al., 2000): (i) in continental arc settings, where mantle melts can be enriched by slab-derived fluids and further may become contaminated with crustal material during ascent (De Paolo, 1981); (ii) in syn- to post-collisional settings, crustal source rocks may melt as a consequence of decompression following delamination of the lithospheric root or slab break off (e.g. Roberts and Clemens, 1993; Liegeois et al.,1994; kwékam et al., 2013).

The high-K calc-alkaline to shoshonite nature of granitoids of Guéra massif suggests that the most suitable protholiths 
could be ancient rocks (Roberts and Clemens, 1993). Compositional differences of melts produced by partial melting of different source rocks, such as amphibolites, tonalitic gneisses, metapelites and metagreywackes, under variable melting conditions can be visualized in terms of molar $\mathrm{CaO} /(\mathrm{MgO}+\mathrm{FeOt})$ vs. molar $\mathrm{Al}_{2} \mathrm{O}_{3} /(\mathrm{MgO}+\mathrm{FeOt}$ ) (Altherr et al.,2000; Fig.11a). In this diagram, most of the samples of the granitoids plot in the field of partial melting from metabasaltic to metatonalitic sources. Few samples of biotite granite and amphibole-biotite granite plot in the field of partial melts from metagreywackes (Fig.11a). This distribution could portray the contribution of the crustal material to its source. Such granite of crustal origin and the contribution of crustal material to the source of granitoids have been demonstrated in the Cameroonian portion of the Adamawa-Yade Domain (Tchameni et al., 2006; Ganwa, 2005). Many I-type granitoids e.g. Ngondo, Batié and Fomopéa (Talla, 1995; Kwékam et al., 2010 and 2013) of west Cameroon show the same characteristics. Intermediate to felsic composition of granitoid is consistent with a derivation from the ancient source of tonalitic to granodioritic composition (Singh and Johannes, 1996). These source rocks are predominantly found in the lower part of the continental crust and we suggest that the source for the biotite granite and amphibole biotite granite was lower amphibolite continental crustal. The abundance of hydrated minerals (amphibole and biotite) in the plutonic rocks suggests that the melting of the protolith took place under hydrous conditions. This source can correspond either to a juvenile crust composed of high-K andesites (Roberts and Clemens, 1993) or to phlogopite-K-richterite enriched lithospheric mantle. In both cases, the main point is that the generation of the high $\mathrm{K}$ calc-alkaline magma needs the former existence of an important subduction phase to generate its source. Gabbro-diorites and amphibole-biotite granites show a moderate negative $\mathrm{Zr}$ anomaly that would suggest a mantle signature. In addition, the position of these rocks in the diagram in figure 8 leads to propose a mantle source for the gabbro-diorites. Highly potassic magnesian characteristics underline their shoshonite affinity. Shoshonites generally result from related subduction enriched lithospheric mantle. This hypothesis is supported by the positions of the Guéra granitoids in the $\mathrm{Ce} / \mathrm{Pb}$ versus $\mathrm{Pb}$ and $\mathrm{La} / \mathrm{Ba}$ versus $\mathrm{La} / \mathrm{Nb}$ diagrams in Figure $10 \mathrm{c}$ and d (Langmuir et al. 1978). In Figure 10d, especially all samples are plotted in the modified-subduction sub-continental lithospheric mantle domain. This domain is the MORB domain enriched by the subduction trench sediments. In addition, the negative $\mathrm{Nb}-\mathrm{Ta}$ and $\mathrm{Ti}$ anomalies and the positive $\mathrm{Pb}$ anomalies (Fig.8), indicate that this mantle source has been modified by the addition of material related to subduction.
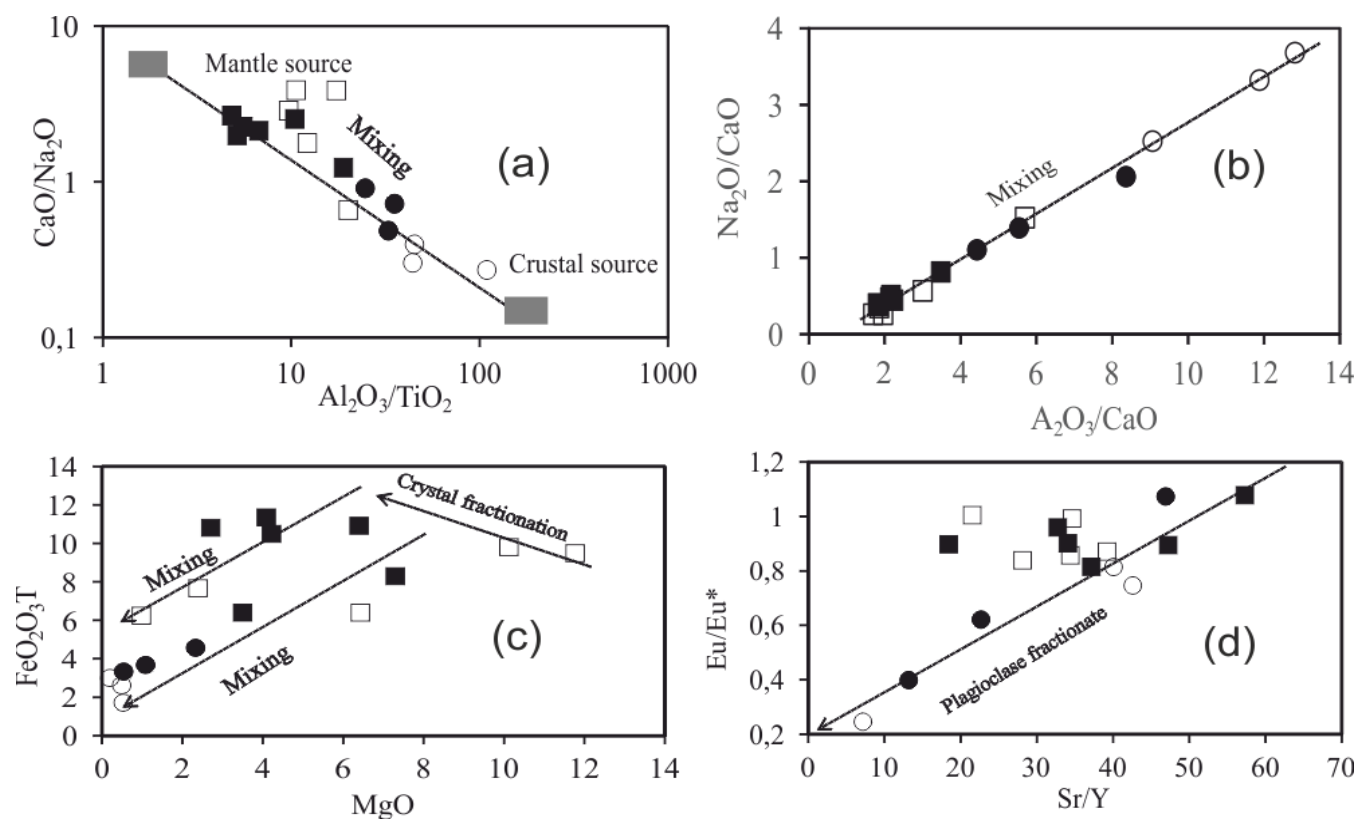

Figure 8. Spider diagrams: Primitive-normalized rare-earth-element diagrams and multi-element plots, values of normalization are from McDonough and Sun (1995) 

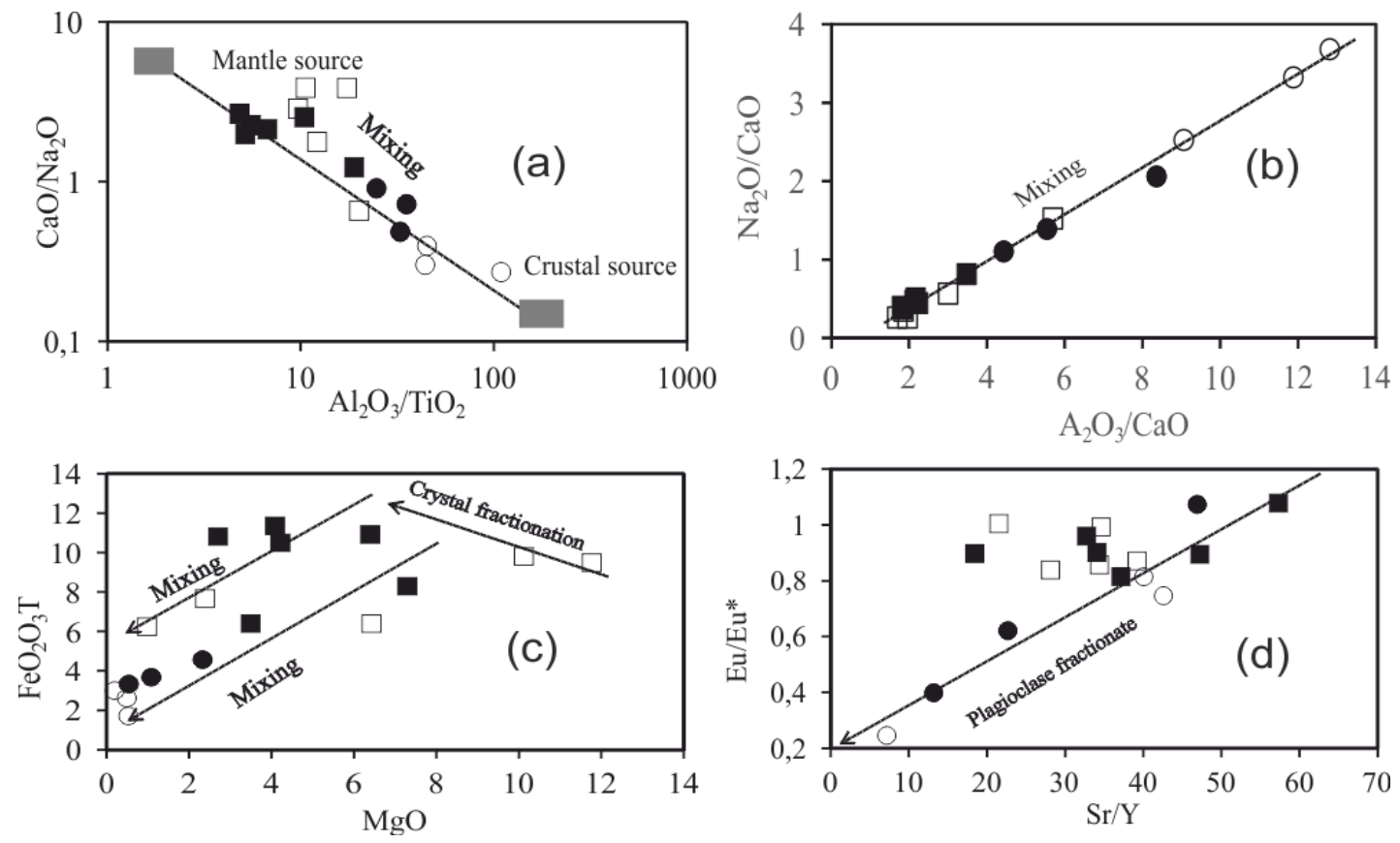

Figure 9. Modelling of mixing, (a) $\mathrm{Al}_{2} \mathrm{O}_{3} / \mathrm{TiO}_{2} \mathrm{vs} \mathrm{CaO} / \mathrm{Na}_{2} \mathrm{O}$ diagram (Chappell and White, 1992 and Sylvester, 1998), (b) $\mathrm{Na}_{2} \mathrm{O} / \mathrm{CaO}$ vs $\mathrm{Al}_{2} \mathrm{O}_{3} / \mathrm{CaO}$ diagram (Chappell and White, 1992) diagrams, (c) $\mathrm{MgO}$ vs $\mathrm{FeOt}$ diagram, the magma mixing curves and fractional curves after Langmuir et al. (1978) and (d) Sr/Y vs Eu/Eu* diagram shows fractional crystallization trend of plagioclase. (Square: Enclaves, Solid square: gabbro-diorites, solid circle: amphibole-biotite granites and circle: biotite granites)
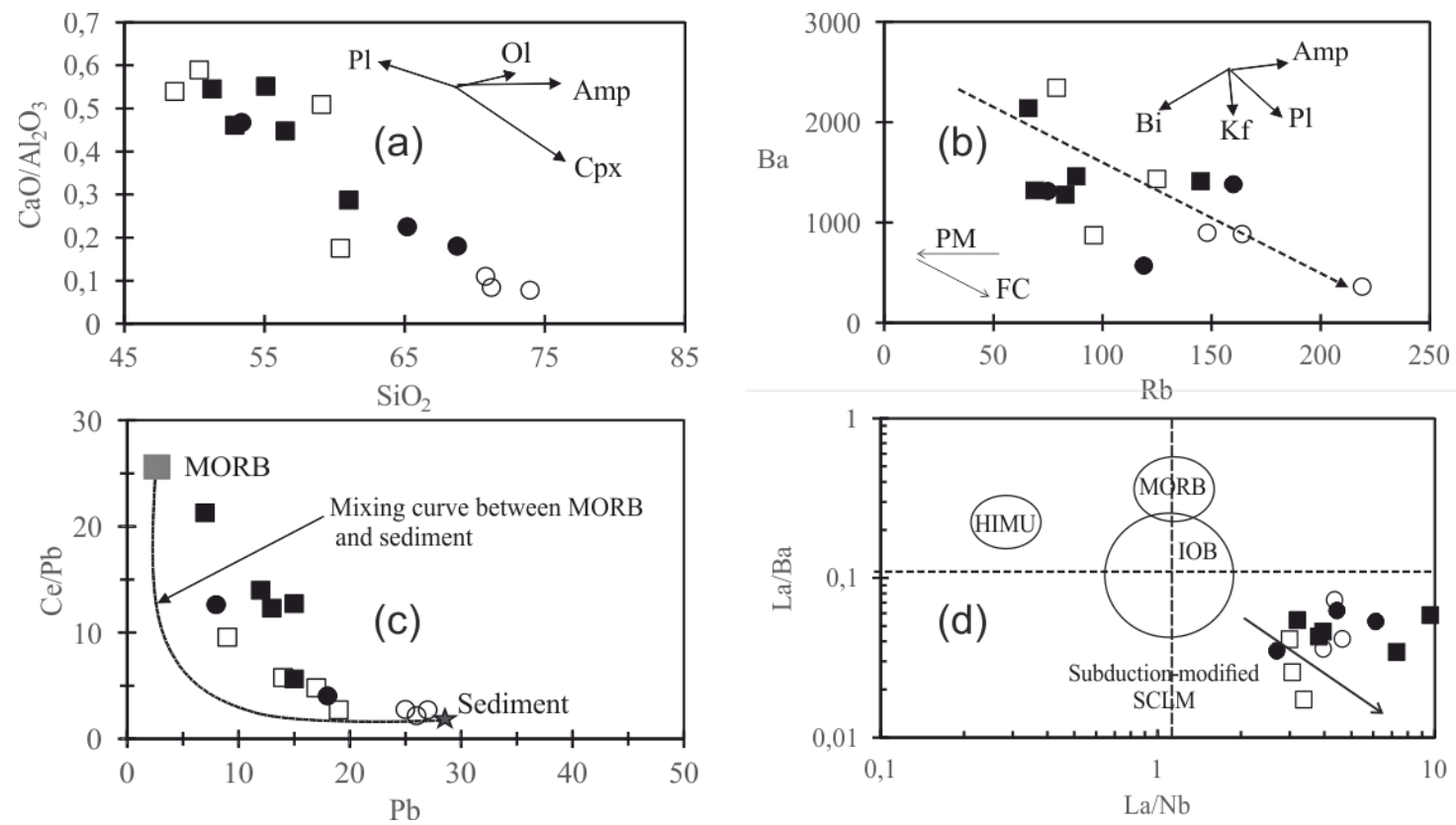

Figure 10. Binary diagrams show evolution of magmas of Guéra granitoids. (a) Plots $\mathrm{CaO} / \mathrm{Al}_{2} \mathrm{O}_{3}$ vs $\mathrm{SiO}_{2}$ and (b) $\mathrm{Ba}$ vs

$\mathrm{Rb}$ display fractionational crystallization of clinopyroxene and plagioclase respectively (Ol, Olivine, Cpx,

Clinopyroxene, Pl, Plagioclase, Amp, Amphibole, Bi, Biotite, Kf, K-feldspar, PM, Partial melting, FC, fractional crystallization), (c) $\mathrm{Ce} / \mathrm{Pb}$ vs $\mathrm{Pb}$ binary mixing diagram (Langmuir et al., 1978) (MORB and sediment values are from

Normand and Garcia (1999) and Gamble et al. (1996), respectively), (d) plot of La/Ba vs La/Nb, sub-continental lithospheric mantle (SCLM) and reference fields for OIB, MORB and high U/Pb mantle source (HIMU) are from Sauders et al. (1992). (Square: Enclaves, Solid square: gabbro-diorites, solid circle: amphibole-biotite granites and circle: biotite granites) 


\subsection{Tectonic Settings}

The Guéra massif is composed of high-K calc-alkaline granitoids that show a volcanic arc geochemical signature (Pearce et al., 1984; Fig. 11b) and are classified as magnesian to ferroan granites. Ferroan granitoids reflect a close affinity to relatively anhydrous, reduced magma and source region. Such conditions are common in extensional environments. Because, these magmas also generally hotter, they are likely to undergo extensive fractionation towards iron-rich, alkali compositions (Forts and Forts, 1997). In contrast, a magnesium series reflects a close affinity to relatively hydrous, oxidizing magmas and region source (Forts and Lindsley, 1991), which is consistent with origins that are broadly subduction related. High-K calc-alkaline magmatism extensively occurs at post-collisional stages (e.g Barbarin,1999, Liégeois et al.,1998) but it also occurs at active continental margins (e.g Barbarin,1999; Wilson, 1989). Strongly magnesian to little ferroan transitional character of granitoid suggests their emplacement during a shift in tectonic regime from a compressive regime to an extensional regime commonly seen in the post-collisional setting of an orogeny (Bonin, 1990). So we can summarize that the granitoids of present study emplaced in the post-collisional setting (Fig. 11b). Futhermore, granitoids of Guéra massif were formed at post-orogenic tectonic environment. Post-orogenic extension is always triggered by the delamination of the subducted slab (Sylvester, 1998; Kwékam et al., 2013; Shellnutt et al., 2017). Thus, delamination inducing an asthenospheric upwelling. Such an upwelling could have caused partial melting of the lithospheric mantle previously metasomatized by subducted materials (Kwékam et al., 2013), forming basaltic magma enriched in LREE, LILE, $\mathrm{H}_{2} \mathrm{O}$ but depleted in $\mathrm{Nb}$, Ta and Ti. The underplating of such basic magma under the lower crust could have triggered partial melting of the mafic lower crust, forming a silicic magma. Mixing and mingling between the basic magma and the silicic magma, followed by crystal fractionation of mafic minerals and accessory minerals, may have led to the formation and evolution of the granitoids of the present area.
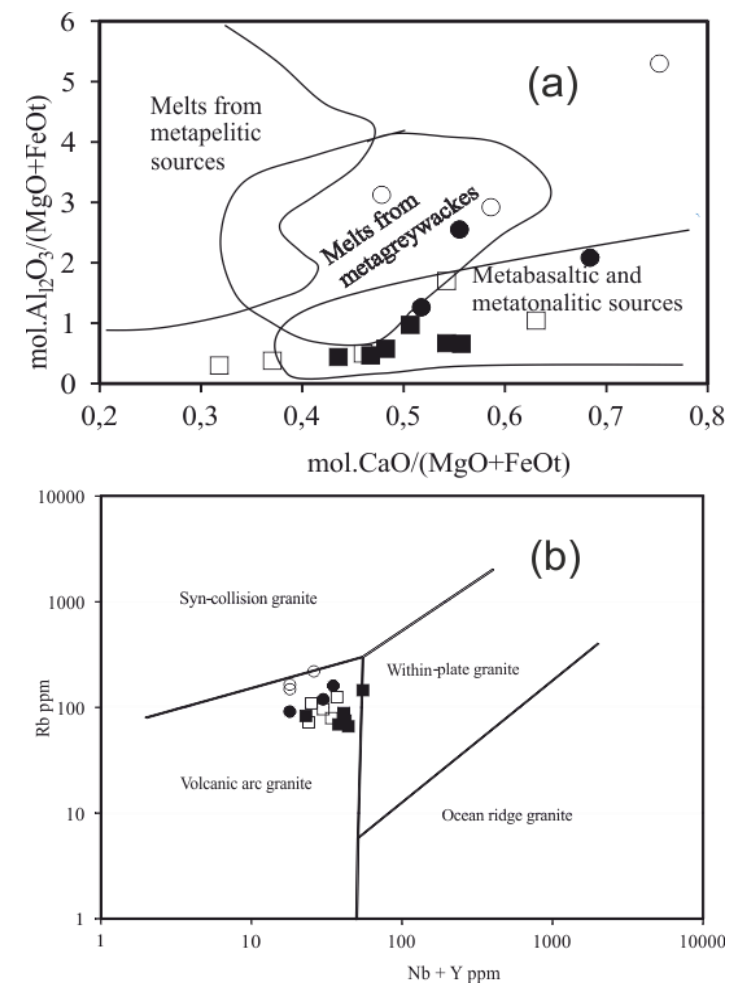

Figure 11. (a) molar $\mathrm{CaO} /(\mathrm{MgO}+\mathrm{FeOt})$ vs molar $\mathrm{Al}_{2} \mathrm{O}_{3} /(\mathrm{MgO}+\mathrm{FeOt}$ ) diagram (Altherr et al., 2000) showing probable magma sources of granitoids, (b) tectonic discrimination diagram (Pearce et al.,1984). (Square: Enclaves, Solid square: gabbro-diorites, solid circle: amphibole-biotite granites and circle: biotite granites)

\section{Conclusion}

Considering the field and petrographic data obtained for the Guéra massif, three groups of granitoid can be distinguished: gabbro-diorite, amphibole-biotite granite and the biotite granite. The main mineral phases that characterize these rocks are alkaline feldspar, quartz, plagioclase, clinopyroxene, with subordinated hornblende and biotite, besides of accessory apatite, zircon and opaque minerals. Whole-rock geochemical data reveal a sub-alkaline affinity for the rocks of the Guéra 
massif, which belongs to high-K calc-alkaline to shoshonitic series. In combination, the field, petrographic and geochemical evidence presented here suggests that mingling and mixing magma processes could be more relevant for the genesis of granitoids of Guéra massif with minor fractionation of plagioclase, clinopyroxene. Although the rocks of the massif appear to have been emplaced in a post-collision context, their magmas have the characteristics of a mantle source modified by the subduction-material. This modified source would have undergone partial melting during the lithospheric delamination of the post-collisional phase of the Pan-African orogeny in Chad.

\section{Acknowledgements}

This article is part of the first author's PhD thesis. Diontar is particularly grateful to the administration of the "Universite Polytechnique de Mongo" for its support during field campaigns and multiple stays at the University of Dschang (Cameroon). We are very thank to anonymous reviewers for their constructive criticisms that significantly improved the manuscript.

\section{References}

Abdelsalam, M., Liégeois, J. P., \& Stern, R. J. (2002). The Saharan Metacraton. Journal of African Earth Sciences, 34, 119-136. http://dx.doi.org/10.1016/S0899-5362(02)00013-1

Altherr, F. F., Holl, A., Hegner, E., Langer, C., \& Kreuzer, H. (2000). High-potassium, calc-alkaline I-type plutonism in the European variscides: northern Vosges (France) and northern Schwarzwald (Germany). Lithos, 50, 51-73, http/dx.doi.org/10.1016/S0024-4937(99)00052-3

Barbarin, B. (1999). A review of the relationships between granitoid types, their origins and their geodynamic environments. Lithos, 46, 605-626. http://dx.doi.org/10.1016/S0024-4937(98)00085-1

Barbarin, B., \& Didier, J. (1992). Genesis and evolution of mafic microgranular enclaves through various types of interaction between coexisting felsic and mafic magmas. Transactions of the Royal Society of Edinburgh: Earth Sciences, 83, 145-153.

Bessoles, B., \& Trompette, R. (1980). La chaîne Pan-Africaine zone mobile d'Afrique centrale (partie sud) et zone mobile soudanaise. Mémoire B.R.G.M. 92, 326 p.

Black, R., \& Liégeois, J-P. (1993). Cratons, mobile belts, alkaline rocks and continental lithospheric mantle: displaced terranes in the Tuareg shield (central Hoggar). Geology, 22, 641-644. https://doi.org/10.1130/0091-7613(1994)022<0641:PADTIT>2.3.CO;2

Bonin, B. (1990). From orogenic to anorogenic settings: evolution of granitoid suites after a major orogenesis. Journal of Geology, 25, 261-270, http://dx.doi.org/10.1002/gj.3350250309

Castaing, C., Feybesse, J. L., Thieblemont, D., Triboulet, C., \& Chevremont, P. (1994). Palaeogeographical reconstructions of the Pan-African/Brasiliano Orogen; closure of an oceanic domain or intracontinental convergence between major blocks? Precambrian Research, 69, 327-344. http://dx.doi.org/10.1016/0301-9268(94)90095-7

Castro, A., De la Rosa, J. D., \& Stephens, W. E. (1990). Magma mixing in the subvolcanic environment: petrology of the Gerena interaction zone near Seville, Spain. Contribution Mineralogy Petrology, 105, 9-26, https://doi.org/10.1007/BF00306405

Castro, A., Moreno-Ventas, I., \& De la Rosa, J. D. (1991). Multistage crystallization of tonalitic enclaves in granitoid rocks (Hercynian belt, Spain): implications for magma mixing. Geology Rundsch, 80, 109-120. https://doi.org/10.1007/BF01828770

Chappell, B. W., \& White, A. J. R. (1974). Two Contrasting Granite Types. Pacific Geology, 8, 173-174.

Chappell, B. W., \& White, A. J. R. (1992). I-and S-type granites in the Lachlan Fold Belt. Transition of the Royal Society Edinburgh: Earth Science, 83, 1-26. http://dx.doi.org/10.1017/S0263593300007720

Clarke, D. B. (1992). Granitoids rocks. Topics in the Earth Sciences, Chapman and Hall, 7, London 283p.

Collins, W. J. (1996). Lachlan Fold Belt granitoids: Products of three component mixing. Transactions of the Royal Society of Edinburgh: Earth Sciences, 88, 171-181. https://doi.org/10.1017/S0263593300006581

Collins, W. J. (1998). Evaluation of petrogenetic models for Lachlan Fold Belt granitoids: Implications for crustal architecture and tectonic models. Australian Journal of Earth Sciences, 45, 483-500, http:/dx.doi.org/10.1080/08120099808728406 
DePaolo, D. J. (1981). A neodymium and strontium isotopic study of the Mesozoic calc-alkaline granitic batholiths of the Sierra Nevada and Peninsular Ranges, California. Journal of Geophysical Research: Solid Earth, 86(B11), 10470-10488. https://doi.org/10.1029/JB086iB11p10470

Didier, J. (1987). Contribution of Enclave Studies to the Understanding of Origin and Evolution of Granitic Magmas. In Enclaves and Granite Petrology, Didier, J. and B. Barbarin (Eds.). Elsevier, Amsterdam. https://doi.org/10.1007/BF01820572

Doumnang, J.-C. (2006). La géologie des formations Néoprotérozö̈ques du Mayo-Kebbi (Sud-Ouest du Tchad). Thèse de Doctorat, Université Orléans, 206p.

Elburg, M. A., \& Nicholls, I. A. (1995). Origin of microgranular enclaves in the S-type Wilson's Promontory Batholith, Victoria: Evidence for magma mingling. Australian Journal of Earth Sciences, 42, 423-435. https://doi.org/10.1080/08120099508728212

Forts, B. R., \& Lindsley, D. H. (1992). Equilibria among Fe-Ti oxides, pyroxenes, olive and quartz: Part II. Application. American Mineralogist, 77, 1004-1020.

Forts, C. D., \& Forts, B. R. (1997). High-K, iron-enriched rapakivi-type granites: the tholeiite connection. Geology, 25, 647-650. https://doi.org/10.1130/0091-7613(1997)025<0647:RRTGTT>2.3.CO;2

Frost, B. R., Barnes, C. G., Collins, W. J., Arculus, R. J., Ellis, D. J., \& Frost, C. D. (2001). A geochemical classification for granitic rocks. Journal of Petrology, 42, 2033-2048. http://dx.doi.org/10.1093/petrology/42.11.2033

Gamble, J., Woodhead, J., Wright, I., \& Smith, I. (1996). Basalt and sediment geochemistry and magma petrogenesis in a transect from oceanic island arc to rifted continental margin arc: the Kermadoc-Hikurangi margin, SW Pacific. Journal of Petrology, 37(6), 1525-1546. https://doi.org/10.1093/petrology/37.6.1523

Ganwa, A. A. (2005). Les granitoîdes de Méiganga: étude pétrographique, géochimique, structurale et géochronologique. Leur place dans la chaîne panafricaine. Doct. d'Etat thesis, Univ. Yaoundé I .

Gray, C. M. (1984). An isotopic mixing model for the origin of granitic rocks in southeastern Australia. Earth and Planetary Science Letters, 70, 47-60. https://doi.org/10.1016/0012-821X(84)90208-5

Gray, C. M., \& Kemp, A. I. S. (2009). The two-component model for the genesis of granitic rocks in southeastern Australia: Nature of the metasedimentary-derived and basaltic end members. Lithos, 111, 113-124. https://doi.org/10.1016/j.lithos.2009.04.010

Hibbard, M. J. (1991). Textural anatomy of twelve magma-mixed granitoid systems. In Enclaves and granite petrology (pp. 431-444).

Hutton, D. H. (1988). Granite emplacement mechanisms and tectonic controls: inferences from deformation studies. Earth and Environmental Science Transactions of the Royal Society of Edinburgh, 79(2-3), 245-255. https://doi.org/10.1017/S0263593300014255

Isseini, M. (2011). Croissance et différenciation crustales au Néoprotérozö̈que: Exemple du domaine panafricain du Mayo Kebbi au Sud-Ouest du Tchad (Doctoral dissertation, Université Henri Poincaré-Nancy 1).

Isseini, M., Hamit, A., \& Abderamane, M. (2013). The tectonic and geologic framework of the Mongo area, a segment of the Pan-African Guera Massif in Central Chad: evidences from field observations and remote sensing. Revue Scientifique du TCHAD, 1(3), 4-12.

Kasser, M-Y. (1995). Evolution précambrienne de la région du Mayo- Kebbi (Tchad). Un segment de la chaîne panafricaine. Thèse Muséum National d'Histoire Naturelle de Paris, 217p.

Keay, S., Collins, W. J., \& McCulloch, M. T. (1997). A three component Sr-Nd isotopic mixing model for granitoid genesis, Lachlan Fold Belt, eastern Australia. Geology, 25, 307-310. https://doi.org/10.1130/0091-7613(1997)025<0307:ATCSNI>2.3.CO;2

Kemp, A. I. S., Hawkesworth, C. J., Foster, G. L., Paterson, B. A., Woodhead, J. D., Hergt, J. M., ... Whitehouse, M. J. (2007). Magmatic and crustal differentiation history of granitic rocks from Hf-O isotopes in zircon. Science, 315, 980-983. http://doi.org/10.1126/science.1136154

Kusnir, I., \& Moutaye, H. A. (1997). Ressources minerals du Tchad: une revue. Journal of African Earth Sciences, 24, 549-562. https://doi.org/10.1016/S0899-5362(97)00080-8

Kwékam, M., Liégeois, J-P., Njonfang, E., Affaton, P., Hartmann, G., \& Tchoua, F. (2010). Nature, origin and significance of the Fomopéa Pan-African high-K calc-alkaline plutonic complex in the central African fold belt (Cameroon). Jouranal of African Earth Sciences, 54, 79-95. http://dx.doi.org/10.1016/j.jafrearsci.2009.07.012 
Kwékam, M., Affaton, P., Bruguier, O., Liégeois, J-P., Hartmann, G., \& Njonfang, E. (2013). The Pan-African Kekem gabbro-norite (West-Cameroon), U-Pb zircon age, geochemistry and Sr-Nd isotopes: geoadynamical implication for the evolution of the Central Africa fold belt. Journal of African Earth Sciences, 84, 70-88. http://dx.doi.org/10.1016/j.jafrearsci.2013.03.010.

Lagmuir, C. H., Vocke, R. D., Hanson, G. N., \& Hart, S. R. (1978). A general mixing equation with applications to Icelandic basalts. Earth and Planetary Science Letters, 37, 380-392. https:/dx.doi.org/10.1016/0012-821X(78)90053-5.

Liégeois, J.-P., Abdelsalam, M. G., Ennih, N., \& Ouabadi, A. (2013). Metacraton: nature, genesis and behavior. Gondwana Research, 23, 220-237, http://dx.doi.org/10.1016/j.gr.2012.02.016.

Liegeois, J-P., Black, R., Navez, J., \& Latouche, L. (1994). Early and late Pan-African orogenies in the Aïr assembly of terranes (Tuareg shield, Niger). Precambrian Research, 68, 335-344. http://dx.doi.org/10.1016/0301-9268(94)90005-1

Liégeois, J-P., Navez, J., Hertogen, J., \& Black, R. (1998). Contrasting origin of post-collisional high-K calc-alkaline and shoshonitic alkaline and peralkaline granitoids. The use of sliding normalization. Lithos, 45, 1-28. http://dx.doi.org/10.1016/S0024-4937(98)00023-1

Louis, P. (1970). Contribution géophysique à la connaissance géologique du bassin du lac Tchad. Bull. ORSTOM, 42.

Maniar, P. D., \& Piccoli, P. M. (1989). Tectonic discrimination of granitoids. Geological Society of American Bulletin, 101, 635-643. https://doi.org/10.1130/0016-7606(1989)101<0635:TDOG>2.3.CO;2

McDonough, W. F., \& Sun, S.-S. (1995). The composition of the Earth. Chemical, 120, 223-253. http://dx.doi.org/10.1016/0009-2541(94)00140-4

Middlemost. (1985). Naming material in the magma/igneous rock system. Earth-Science Review, 37, 215-224. https://doi.org/10.1016/0012-8252(94)90029-9

Nabelek, P. I., \& Liu, M. (2004). Petrogic and thermal constraints on the origin of leucogranites in collisional orogens. Earth and Environmental Science and environment Transactions of the Royal Society of Edinburgh, 95, 73-85. https://doi.org/10.1017/S0263593300000936

Ngako, V., Affaton, P., \& Njonfang, E. (2008). Pan-African tectonics in northwestern Cameroon: implication for the history of western Gondwana. Gondwana Research, 14, 509-522. http://dx.doi.org/10.1016/j.gr.2008.02.002

Norman, C. D., \& Garcia, C. O. (1999). Primitive magmas and source characteristics of the Hawaiian plume: petrology and geochemistry of shield picrites. Earth and Planetary Science Letters, 168, 27-44. http://dx.doi.org/10.1016/s0012-821x(99)00043-6

Pearce, J. A., Harris, N. B., \& Tindle, A. G. (1984). Trace element discrimination diagrams for the tectonic interpretation of granitic rocks. Journal of Petrology, 25, 956-983. http://dx.doi.org/10.1093/petrology/25.4.956

Penaye, J., Kroner, A., Toteu, S. F., Van Schmus, W. R., \& Doumnang, J. C. (2006). Evolution of the Mayo Kebbi region as reveal by zircon dating: an early (ca. $740 \mathrm{Ma}$ ) Pan-African magmatic arc in south-western Chad. Journal of African Earth Sciences, 44, 530-542. http:/dx.doi.org/10.1016/j.jafrearsci.2005.11.018

Pham, N. H. T., Shellnutt, J. G., Yeh, M.-W., \& Lee, T.-Y. (2017). A-type granites from the Guéra Massif, Central Chad: Petrology, geochemistry, geochronology, and petrogenesis. EGU General Assembly Conference Abstracts, 19, 6211

Pin, C., \& Podevin, J. L. (1987). U-Pb zircon evidence for a Pan-African granulite facies metamorphism in the Central African Republic. A new interpretation of the high grade series of the northern border of the Congo Craton. Precambrian Research, 36, 303-312. https://doi.org/10.1016/0301-9268(87)90027-1

Poli, G., \& Tommasini, S. (1999). Geochemical modeling of acid-basic magma interaction in the Sardinia-Corsica Batholith: the case study of Sarrabus, southeastern Sardinia, Italy. Lithos, 46, 553-571. https://doi.org/10.1016/S0024-4937(98)00082-6

Pouclet, A., Vidal, M., Doumnang, J.-C., Vicat, J. P., \& Tchameni, R. (2006). Neoproterozoic crustal evolution in Southern Chad: Pan-African ocean basin closing, arc accretion and late- to post-orogenic granitic intrusion. Journal of African Earth Sciences, 44, 543-560. http:/dx.doi.org/10.1016/j.jafrearsci.2005.11.019

Rickwood, P. C. (1989). Boundary lines within petrologic diagrams which use oxides of major and minor elements. Lithos, 22, 247-264. http://dx.doi.org/10.1016/0024-4937(89)90028-5

Roberts, M. P., \& Clemens, J. D. (1993). Origin of high-potassium, calcalkaline, I-type granitoids. Geology, 21, 825-828. http://dx.doi.org/10.1130/0091-7613(1993)021<0825:00HPTA >2.3.CO:2 
Rollinson, H. R. (1993). Using Geochemical Data: Evaluation, Presentation and Interpretation. Wiley, New York.

Saunders, A. D., Storey, M., Kent, R. W., \& Norry, M. J. (1992). Co,sequences of plume lithosphere interactions. Magmatism and the cause of continental breakup. Geological Society of London, Special publication, 68, 41-60. https://doi.org/10.1144/GSL.SP.1992.068.01.04

Shellnutt, J. G., Pham, N. H. T., Denyszyn, S. W., Yeh, M. W., \& Lee, T-Y. (2017). Timing of collisional and post-collisional Pan-African Orogeny silicic magmatism in south-central Chad. Precambr Res., 301, 113-123. https://doi.org/10.1016/j.precamres.2017.08.021

Silva, M. M. V. G., Neiva, A. M. R., \& Whitehouse, M. J. (2000). Geochemistry of enclaves and host granite from the Nelas area, central Portugal. Lithos, 50, 153-170. https:/doi.org/10.1016/S0024-4937(99)00053-5

Singh, J., \& Johannes, W. (1996). Dehydration Melting of Tonalites. Part I. Beginning of Melting. Contribution to Mineralogy and Petrology, 125, 16-25. https://doi.org/10.1007/s004100050203

Streckeisen, A., \& le Maitre, R. W. (1979). A chemical approximation to the modal QAPF classification of igneous rocks. Neues Jahrbuch Mineralogische Abhandlungen, 136, 169-206.

Stremțan, C., Balica, C., Savov, I., Ryan, J., \& Balintoni, I. (2013). The Role of the Mantle in Variscan Post-collisional Magmatism - Insights from Muntele Mic and Culmea Cernei Plutons (Romanian Southern Carpathians). Geophysical Research Abstracts 15 (EGU2013-10002).

Sylvester, P. J. (1998). Post-collisional strongly peraluminous granites. Lithos 45, 29-44. https://doi.org/10.1016/S0024-4937(98)00024-3

Talla, V. (1995). Le Massif granitic panafricain de Batié (Ouest-Cameroun): Pétrologie Pétrostructurale-Géochimie. Thèse de Doctorat, Université de Yaoundé I, 144p.

Tchameni, R., Pouclet, A., Penaye, J., Ganwa, A. A., \& Toteu, S. F. (2006). Petrography and Geochemistry of the Ngaoundéré Pan-African Granitoids in Central North Cameroon: Implications for Their Sources and Geological Setting. Journal of African Earth Sciences, 44, 511-529. http://dx.doi.org/10.1016/j.jafrearsci.2005.11.017

Tindle, A. G. (1991). Trace element behaviour in microgranular enclaves from granitic rocks. In: Enclaves and Granite Petrology. Developments in Petrology 13: Didier, J. and Barbarin, B. (eds.) Elsevier, Amsterdam, 313-332.

Tobisch, O. T., McNulty, B. A., \& Vernon, R. H. (1997). Microgranitoid enclave swarms in granitic plutons, central Sierra Nevada, California. Lithos, 40, 321- 339. https://doi.org/10.1016/S0024-4937(97)00004-2

Toteu, S. F., Penaye, J., \& Djomani, Y. P. (2004). Geodynamic evolution of the Pan-African belt in central Africa with special reference to Cameroon. Can. J. Earth Sci., 41, 73-85. https://doi.org/10.1139/e03-079

Vernon, R. H. (1983). Restite, xenoliths and microgranitoid enclaves in granites. Journal of Proceedings, Royal Society of New South Wales, 116, 77-103. http://dx.doi.org/10.1080/08120099.2014.886623

Vernon, R. H. (1991). Interpretation of Microstructures of microgranitoid. Enclaves. In: Enclaves and Granite Petrology 13, Didier J. and B. Barbarin (Eds). 1sevier. Amsterdam ISBN: 0-444-89145-5, 277-292.

Wiebe, R. A. (1991). Commingling of contrasted magmas in the plutonic environment: Examples from the Nain Anorthositic Complex. Journal of Geology, 88, 197-209. https://doi.org/10.1086/628491

Wiebe, R. A. (1994). Silicic magma chambers as traps for basaltic magmas: the Cadillac Mountain Intrusive Complex. Journal of Geology, 102, 423-437. https://www.jstor.org/stable/30065661

Wiebe, R. A. (1996). Mafic-silicic layered intrusions: the role of basaltic injections on magmatic processes and the evolution of silicic magma chambers. Trans. R. Soc. Edinb. Earth Sci., 87, 233-242. https://doi.org/10.1017/S0263593300006647

Wilson, M. (1989). Igneous petrogenesis: A global tectonic approach. Chapman \& Hall, London, 13-34. https://doi.org/10.1007/978-1-4020-6788-4

Wyllie P. J. (1984). Sources of granitoid magmas at convergent plate boundaries. Physics of the Earth and Planetary Interiors, 35, 12-18. https://doi.org/10.1016/0031-9201(84)90030-X

Zhou, X. R. (1994). Hybridization in the genesis of granitoids. Frontiers of Earth Science, 1, 77-97.

Zorpi, M. J., Coulon, C., Orsini, J. B., \& Cocirta, C. (1989). Magma mingling, zoning and emplacement in calc-alkaline granitoid plutons. Tectonophysics, 157, 315-329. https://doi.org/10.1016/0040-1951(89)90147-9 


\section{Copyrights}

Copyright for this article is retained by the author(s), with first publication rights granted to the journal.

This is an open-access article distributed under the terms and conditions of the Creative Commons Attribution license (http://creativecommons.org/licenses/by/4.0/). 